\title{
Origins and composition of fine atmospheric carbonaceous aerosol in the Sierra Nevada Mountains, California
}

\author{
D. R. Worton ${ }^{1,2}$, A. H. Goldstein ${ }^{1,3}$, D. K. Farmer ${ }^{4,5}$, K. S. Docherty ${ }^{4,5,{ }^{*} \text {, J. L. Jimenez }}{ }^{4,5}$, J. B. Gilman ${ }^{4,6}$, \\ W. C. Kuster ${ }^{6}$, J. de Gouw ${ }^{4,6}$, B. J. Williams ${ }^{7}$, N. M. Kreisberg ${ }^{2}$, S. V. Hering ${ }^{2}$, G. Bench ${ }^{8}$, M. McKay ${ }^{1, * *}$, \\ K. Kristensen ${ }^{9}$, M. Glasius ${ }^{9}$, J. D. Surratt ${ }^{10, * * *}$, and J. H. Seinfeld ${ }^{11}$ \\ ${ }^{1}$ Department of Environmental Science, Policy and Management, University of California, Berkeley, CA, 94720, USA \\ ${ }^{2}$ Aerosol Dynamics Inc., Berkeley, CA, 94710, USA \\ ${ }^{3}$ Department of Civil and Environmental Engineering, University of California, Berkeley, CA, 94720, USA \\ ${ }^{4}$ Cooperative Institute for Research in Environmental Sciences, University of Colorado, Boulder, CO, 80309, USA \\ ${ }^{5}$ Department of Chemistry and Biochemistry, University of Colorado, Boulder, CO, 80309, USA \\ ${ }^{6}$ NOAA Earth System Research Laboratory, Boulder, CO, 80305, USA \\ ${ }^{7}$ Energy, Environmental and Chemical Engineering, Washington University, St. Louis, MO, 63130, USA \\ ${ }^{8}$ Center for Accelerator Mass Spectrometry, Lawrence Livermore National Laboratory, Livermore, CA, 94550, USA \\ ${ }^{9}$ Department of Chemistry, University of Aarhus, Aarhus C, 8000, Denmark \\ ${ }^{10}$ Department of Chemistry, California Institute of Technology, Pasadena, CA, 91125, USA \\ ${ }^{11}$ Departments of Environmental Science and Engineering and Chemical Engineering, California Institute of Technology, \\ Pasadena, CA, 91125, USA \\ *now at: Alion Science and Technology, EPA Office of Research and Development, EPA Research and Development, \\ Research Triangle Park, NC, USA \\ ***w at: California Air Resources Board, Sacramento, CA, USA \\ *** now at: Department of Environmental Sciences and Engineering, University of North Carolina at Chapel Hill, Chapel Hill, \\ NC, 27599, USA
}

Received: 1 June 2011 - Published in Atmos. Chem. Phys. Discuss.: 20 June 2011

Revised: 23 September 2011 - Accepted: 26 September 2011 - Published: 12 October 2011

\begin{abstract}
In this paper we report chemically resolved measurements of organic aerosol (OA) and related tracers during the Biosphere Effects on Aerosols and Photochemistry Experiment (BEARPEX) at the Blodgett Forest Research Station, California from 15 August-10 October 2007. OA contributed the majority of the mass to the fine atmospheric particles and was predominately oxygenated (OOA). The highest concentrations of $\mathrm{OA}$ were during sporadic wildfire influence when aged plumes were impacting the site. In situ measurements of particle phase molecular markers were dominated by secondary compounds and along with gas phase compounds could be categorized into six factors or sources: (1) aged biomass burning emissions and oxidized urban emissions, (2) oxidized urban emissions (3) oxidation products of monoterpene emissions, (4) monoterpene emissions, (5) anthropogenic emissions and (6) local methyl chavicol emissions and oxidation products. There were mul-
\end{abstract}

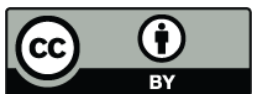

Correspondence to: D. R. Worton (dworton@berkeley.edu) tiple biogenic components that contributed to OA at this site whose contributions varied diurnally, seasonally and in response to changing meteorological conditions, e.g. temperature and precipitation events. Concentrations of isoprene oxidation products were larger when temperatures were higher during the first half of the campaign (15 August-12 September) due to more substantial emissions of isoprene and enhanced photochemistry. The oxidation of methyl chavicol, an oxygenated terpene emitted by ponderosa pine trees, contributed similarly to OA throughout the campaign. In contrast, the abundances of monoterpene oxidation products in the particle phase were greater during the cooler conditions in the latter half of the campaign (13 September-10 October), even though emissions of the precursors were lower, although the mechanism is not known. OA was correlated with the anthropogenic tracers 2-propyl nitrate and carbon monoxide (CO), consistent with previous observations, while being comprised of mostly non-fossil carbon $(>75 \%)$. The correlation between OA and an anthropogenic tracer does not necessarily identify the source of the carbon as being

Published by Copernicus Publications on behalf of the European Geosciences Union. 
anthropogenic but instead suggests a coupling between the anthropogenic and biogenic components in the air mass that might be related to the source of the oxidant and/or the aerosol sulfate. Observations of organosulfates of isoprene and $\alpha$-pinene provided evidence for the likely importance of aerosol sulfate in spite of neutralized aerosol although acidic plumes might have played a role upwind of the site. This is in contrast to laboratory studies where strongly acidic seed aerosols were needed in order to form these compounds. These compounds together represented only a minor fraction $(<1 \%)$ of the total OA mass, which may be the result of the neutralized aerosol at the site or because only a small number of organosulfates were quantified. The low contribution of organosulfates to total OA suggests that other mechanisms, e.g. $\mathrm{NO}_{\mathrm{x}}$ enhancement of oxidant levels, are likely responsible for the majority of the anthropogenic enhancement of biogenic secondary organic aerosol observed at this site.

\section{Introduction}

Fine atmospheric particulate matter, defined as having aerodynamic diameters less than $2.5 \mu \mathrm{m}\left(\mathrm{PM}_{2.5}\right)$, affects visibility, human health and the Earth's climate. Organic aerosols (OA) constitute an important fraction (20-90\%) of the fine particle mass (Kanakidou et al., 2005) and are ubiquitous throughout the Northern Hemisphere (Zhang et al., 2007a). OA originates from both anthropogenic and biogenic sources and can be emitted directly to the atmosphere as primary organic aerosol (POA) or formed through gas to particle conversion of low-volatility compounds as secondary organic aerosol (SOA) (Seinfeld and Pankow, 2003). SOA accounts for the majority of the total organic mass of aerosols (Zhang et al., 2005, 2007a) and traditional models likely underestimate SOA by factors of 2-10 in polluted regions (Heald et al., 2005, 2010; Volkamer et al., 2006; de Gouw et al., 2005; Spracklen et al., 2011), but not in "clean" biogenic regions (e.g. Tunved et al., 2006; Chen et al., 2009; Hodzic et al., 2010b; Slowik et al., 2010). More recent models achieve closure and even over-predict SOA formation in polluted regions, but a low level of confidence remains in the identification of the important precursors and pathways for the observed SOA (Dzepina et al., 2009; Tsimpidi et al., 2010; Hodzic et al., 2010a). Possible hypotheses for the observed OA discrepancies between measurements and models are: (1) as yet unidentified precursor species not included in traditional models (Goldstein and Galbally, 2007), including semi- and intermediate volatility compounds, SVOC and IVOC, respectively (de Gouw et al., 2011; Robinson et al., 2007), (2) higher yields of known precursors than included in traditional models (Tsimpidi et al., 2010), (3) aqueous chemistry in clouds and aerosols, (Ervens et al., 2008) and (4) heterogeneous uptake of gas phase species, e.g. glyoxal (Volkamer et al., 2007; Kroll et al., 2005).
Since estimated emissions of biogenic volatile organic compounds (BVOCs) exceed those of anthropogenic VOC emissions by over an order of magnitude (Guenther et al., 1995; Middleton, 1995) global models have traditionally attributed a large fraction of SOA to biogenic sources (Kanakidou et al., 2005). However, recent global modeling studies suggest a substantial global role for anthropogenic or anthropogenically-influenced SOA formation (Spracklen et al., 2011; Pye and Seinfeld, 2010). The contributions of anthropogenic and biogenic sources to OA have previously been estimated using several indirect approaches, e.g. chemical mass balance (CMB) (Schauer et al., 1996; Kleindienst et al., 2010), organic tracer based method (Offenberg et al., 2011) and measurements of the radiogenic carbon $\left({ }^{14} \mathrm{C}\right)$ content (Szidat et al., 2004). The determination of the ${ }^{14} \mathrm{C}$ content provides mass weighted source apportionment of carbonaceous aerosol particles due to the direct distinction between non-fossil and fossil carbon. Radiogenic carbon $\left({ }^{14} \mathrm{C}\right)$ is present in a small but approximately constant level in contemporary or living materials but is absent in fossil fuels as a result of radioactive decay. Moreover, ${ }^{14} \mathrm{C}$ is a robust "tracer" as it retains its identity throughout any chemical transformation. Recently, this approach has been used to show that a large fraction of carbonaceous aerosol in the United States is non-fossil in origin; $\sim 50 \%$ in urban areas and $70-100 \%$ in near urban and remote sites (e.g. Bench et al., 2007; Schichtel et al., 2008). Not all this non-fossil carbon in aerosols can be attributed to SOA formed from BVOC oxidation because there are important contributions from biomass burning, biofuel use, and non-fossil urban OA sources (such as cooking). It is possible that $\sim 30 \%$ of the non-fossil carbon in urban areas is attributable to urban sources (Hildemann et al., 1994; Hodzic et al., 2010b), which has implications for the interpretation of the magnitude of the non-fossil fraction. However this fraction has not been characterized in northern California.

In previous studies, OA has been observed to be correlated with tracers of anthropogenic influence, e.g. CO (Sullivan et al., 2006; Weber et al., 2007; Bahreini et al., 2009) and alkyl nitrates (de Gouw et al., 2005). Similar proportions of OA to 2-propyl nitrate were observed in the northeastern United States and northern Georgia despite major differences (10-100 times) in BVOC concentrations. ${ }^{14} \mathrm{C}$ measurements associated with the northern Georgia dataset indicate that the water soluble organic carbon (WSOC) was predominantly (>70\%) non-fossil and a substantial fraction was likely formed through secondary processes involving BVOC and an anthropogenic component that may be the controlling factor (Weber et al., 2007). It has been suggested that biogenic SOA formation may be enhanced in polluted air (Goldstein et al., 2009; Weber et al., 2007; Hoyle et al., 2011; Spracklen et al., 2011) and several recent studies have suggested a possible coupling between anthropogenically emitted species and BVOCs in SOA formation, e.g. (i) the nocturnal oxidation of isoprene by $\mathrm{NO}_{3}$ contributed, on average, 
$\sim 6 \%$ to SOA in the northeastern United States and exceeded SOA derived from $\mathrm{OH}$ photooxidation of isoprene by $\sim 50 \%$ (Brown et al., 2009), (ii) Chan et al. (2010) showed that the aerosol yield from isoprene photooxidation was strongly dependent on the $\mathrm{NO}_{2}: \mathrm{NO}$ ratio under high- $\mathrm{NO}_{\mathrm{x}}$ conditions and also reported the highest aerosol yields $(\sim 7 \%)$ for isoprene oxidation with $\mathrm{NO}_{2}$ : $\mathrm{NO}$ ratios of $>5: 1$, and (iii) Surratt et al. $(2006,2007)$ have shown the presence of particle-phase organosulfate and nitroxyorganosulfate compounds derived from the oxidation of BVOCs, which have been estimated to contribute $\sim 10 \%$ to the total organic aerosol mass in some locations (Surratt et al., 2008).

The formation of organosulfates has been speculated to be a major contributor to the observed enhancements in laboratory SOA yields in the presence of acidic aerosols (Surratt et al., 2007; Chan et al., 2010, 2011). Previous chamber studies of anthropogenic precursor oxidation have not shown as strong a dependence of SOA mass on the presence of aerosol acidity as for BVOCs (Ng et al., 2007). This suggests that uptake of BVOC oxidation products to produce organosulfates could be a mechanism that selectively incorporates nonfossil carbon into the condensed phase while maintaining a dependence of $\mathrm{OA}$ on anthropogenic emissions, i.e. sulfur dioxide $\left(\mathrm{SO}_{2}\right)$. As $\mathrm{SO}_{2}$ emissions are strongly related to combustion, a substantial source of both carbon monoxide (CO) and $\mathrm{NO}_{\mathrm{x}}$, this would be consistent with the observations of correlations between OA and both $\mathrm{CO}$ and alkyl nitrates, although in some locations where $\mathrm{CO}$ and $\mathrm{SO}_{\mathrm{x}}$ were not correlated, SOA was still correlated with CO (DeCarlo et al., 2010). However, previous field measurements have not observed evidence of acid-catalyzed SOA formation, e.g. in power plant plumes over Atlanta, Georgia (Peltier et al., 2007) or in Pittsburgh, Pennsylvania (Takahama et al., 2006; Zhang et al., 2007b). This suggests there may be important differences between organosulfate formation observed in the laboratory relative to the atmosphere, which has implications for the interpretation of ambient data using models informed from smog chamber experiments.

The implications of the couplings between anthropogenic and biogenic compounds in SOA formation are that the presence of substantial biogenic carbon does not necessarily mean that aerosols are natural, i.e. uncontrolled by anthropogenic emissions. Indeed, a recent regional modeling study has illustrated the potential influence of anthropogenic emissions, in particular primary organic particulate matter and nitrogen oxides $\left(\mathrm{NO}_{\mathrm{x}}\right)$ on increasing biogenic SOA formation by a factor of 2 (Carlton et al., 2010). They showed that in their model higher $\mathrm{NO}_{\mathrm{x}}$ concentrations generated more ozone that led to increased hydroxyl radical $(\mathrm{OH})$ concentrations and enhanced oxidation of BVOCs, and POA and SOA from anthropogenic and biomass burning emissions lead to enhanced partitioning of BSOA. A global modeling study has suggested an even larger enhancement approaching an order of magnitude, whose mechanistic causes are not understood (Spracklen et al., 2011).
In this paper, we report measurements made at the Blodgett Forest Research Station during the Biosphere Effects on Aerosols and Photochemistry Experiment (BEARPEX). The site is located between the city of Sacramento and Lake Tahoe and is impacted by both urban emissions and substantial biogenic sources that are located both upwind of and at the site. Previous work at this site has shown that: (i) chemical loss of ozone was likely due to gas-phase reactions with BVOCs emitted from the forest in a similar temperature dependent manner to terpenes (Kurpius and Goldstein, 2003; Goldstein et al., 2004), (ii) there is a substantial flux of reactive monoterpenes, sesquiterpenes and methyl chavicol from the forest to the atmosphere (Holzinger et al., 2005; BouvierBrown et al., 2009a, b), and (iii) the presence of large quantities of BVOC oxidation products above the canopy indicates substantial oxidation of BVOCs within the forest canopy (Holzinger et al., 2005). Lunden et al. (2006) observed fine aerosol growth events at the Blodgett Forest site, which are understood to be related to terpene oxidation within the forest canopy. Previous filter measurements at the site (Cahill et al., 2006) have shown the presence of several known biogenic oxidation products in the particle phase whose concentrations were substantially elevated at night. This site provides an opportunity to examine aerosol formation in a low $\mathrm{NO}_{\mathrm{x}}$, high VOC regime with substantial contributions from biogenic sources. In this work, we use chemically resolved measurements of organic aerosol and related tracers to characterize the chemical composition of carbonaceous aerosols, determine their sources at Blodgett Forest and investigate the coupling between anthropogenic and biogenic emissions in the formation of SOA in this environment.

\section{Experimental methodology}

\subsection{Site description}

The BEARPEX campaign took place at a ponderosa pine (Pinus ponderosa L.) plantation owned by Sierra Pacific Industries adjacent to the University of California - Blodgett Forest Research Station (UC-BFRS; $38.90^{\circ} \mathrm{N}, 120.63^{\circ} \mathrm{W}$, $1315 \mathrm{~m}$ elevation above sea level). The site is located between Sacramento and Lake Tahoe in the Sierra Nevada Mountains, California, and was established as an atmospheric measurement site in 1997 (Goldstein et al., 2000). The site was planted with ponderosa pine in 1990, which in 2007 had a mean height of $8 \mathrm{~m}$. The understory is composed primarily of Manzanita (Arctostaphylos spp.) and whitethorn (Ceonothus cordulatus) shrubs. The campaign ran from 15 August to 10 October 2007 and captured two distinct meteorological periods, the first from 15 August-12 September period was characterized by hot and dry conditions and sporadic influence of smoke from various California wildfires. A sharp decline in temperature and a simultaneous increase in relative humidity occurred between 12 and 13 September, 
which led to cooler and wetter conditions that persisted for the remainder of the campaign. This later period also experienced several precipitation events on 20, 22, 23 September and snow on 5 October.

\subsection{In situ measurements}

A wide range of instrumentation measuring concentrations, gradients and fluxes of a broad suite of gas- and particlephase constituents were deployed during the BEARPEX campaign providing a very comprehensive dataset. Measurements included ozone, nitrogen oxides, nitric and nitrous acid, organic nitrates, organic peroxides, formaldehyde, glyoxal, volatile organic compounds, chemically resolved aerosol speciation and speciated organic aerosol composition. In this section we describe only the measurements discussed in this paper.

Measurements of non-refractory $\mathrm{PM}_{1}$ aerosol components were made using a high-resolution time-of-flight aerosol mass spectrometer (HR-ToF-AMS; Aerodyne Research Inc.) for 42 days from 19 August-29 September 2007. The operation of the AMS has been described in detail elsewhere (Jimenez et al., 2003; Jayne et al., 2000; DeCarlo et al., 2006) and details specific to BEARPEX were described by Farmer et al. (2011). In brief, aerosol particles were continuously drawn through a dedicated $\frac{1}{2}$ " insulated copper inlet from $25 \mathrm{~m}$ at the top of the north tower and were focused through an aerodynamic lens and impacted onto a vaporizer held at $\sim 600^{\circ} \mathrm{C}$. The vapors were ionized with electron ionization and the resultant ions were detected by ToF/MS. Chemically resolved mass concentrations of individual components (organics, sulfate, nitrate, ammonium and chloride) were extracted from the AMS raw data following the work of Allan et al. (2004) and DeCarlo et al. (2006). The organic fraction was further separated into "oxygenated" (OOA) and "hydrocarbon-like" (HOA) using a positive matrix factorization approach, previously described by Ulbrich et al. (2009).

A wide range of volatile organic compounds (VOC) and oxygenated volatile organic carbon (OVOC) compounds were measured by two independent in situ GC/MS instruments operated by the University of California, Berkeley (Bouvier-Brown et al., 2009a, b) and by the National Oceanic and Atmospheric Administration (NOAA) (Gilman et al., 2010) for 51 and 39 days from 20 August-10 October 2007 and 21 August-28 September, respectively. Detailed descriptions of both these instruments have previously been published for this campaign by Bouvier-Brown et al. (2009a, 2009b). The influence of gaseous emissions from the propane generator, which was used to power the site and whose emissions were frequently observed at the site during low windspeeds, has been removed by filtering the data for acetylene to benzene ratios greater than 10:1.

Speciated measurements of molecular marker compounds in aerosols were made by thermal desorption aerosol gas chromatography (TAG) coupled with mass spectrometry for
31 days from 7 September-8 October 2007. This instrument has been described in detail by Williams et al. (2006) and further developments to the TAG system have been discussed in Williams et al. (2007) and Kreisberg et al. (2009). Thus, only a brief description is given here. Aerosol samples $\left(\mathrm{PM}_{2.5}\right)$ were drawn at a sampling rate of $91 \mathrm{~min}^{-1}$ for $90 \mathrm{~min}$ (sample volume $0.81 \mathrm{~m}^{3}$ ) from a dedicated insulated stainless steel inlet line from a height of approximately $9.2 \mathrm{~m}$. Aerosols were humidified and impacted in a custom collection and thermal desorption cell (CTD) at ambient temperature. Following sample collection, the CTD was then heated to $300^{\circ} \mathrm{C}$ to transfer and refocus all the analytes onto the head of the chromatographic column; analytes were detected by electron ionization quadrupole mass spectrometry operated in full scan mode with $\mathrm{m} / \mathrm{z}$, range of 29-400. The introduction of calibration standards was done manually, as described by Kreisberg et al. (2009). Several instrumental improvements, not described in previous publications, were made prior to the BEARPEX campaign. Firstly, all temperature controls, valve switching and data logging were controlled using in-house written software (Labview, National Instruments). Secondly, the thermal control system of two critical sample transfer lines was redesigned. This involved encapsulating each transfer tube in an aluminum block to increase the thermal mass facilitating higher $\left(300^{\circ} \mathrm{C}\right)$ and more consistent temperature control. The improved transfer efficiency achieved by these refinements was tested using an n-alkane injection standard. The improved system detects compounds with vapor pressures down to the equivalent of tetracontane $\left(\mathrm{C}_{40}\right.$ alkane; subcooled liquid vapor pressure $=2.73 \times 10^{-7} \mathrm{~Pa}$ at $298 \mathrm{~K}$, saturation concentration $c^{*}=0.06 \mu \mathrm{g} \mathrm{m}^{-3}$ ) that were not observed with the unmodified instrument (Kreisberg et al., 2009). Finally, active heating control of the humidifier was introduced to ensure bounce-free particle collection through maintaining a relative humidity of $>75 \%$ in the collection and thermal desorption cell during sampling. To avoid condensing any water between the humidifier and the cell, an additional heating element and PID controller were used to maintain the connecting plumbing between the cell and humidifier approximately $2{ }^{\circ} \mathrm{C}$ above the cell temperature. With this setup it was possible to maintain the cell relative humidity between $75 \%$ and $85 \%$ under nearly all ambient sampling conditions encountered and thus provide bounce-free collection of $0.08-2.5 \mu \mathrm{m}$ particles.

\subsection{Offline filter measurements}

The speciated molecular markers that are measurable by TAG span a wide range of organic compounds (Williams et al., 2006, 2007, 2010b) but TAG performs best for species that are in the low to intermediate polarity range (e.g. nalkanes to $>\mathrm{C}_{10}$ monocarboxylic acids) and typically with carbon to oxygen $(\mathrm{O} / \mathrm{C})$ ratios of 0.3 or less, though some compounds have been observed by TAG that have an O/C 
of up to 0.6 (Williams et al., 2010a), comparable to the SVOOA (previously OOA-2) factor frequently described from AMS measurements (Aiken et al., 2008; Jimenez et al., 2009). Highly oxidized and thermally labile components do not pass through the chromatography column or are decomposed during thermal desorption and thus either do not reach the detector or are not detected in their original form. Lower time resolution filter measurements of these types of compounds can be a useful complement to the high time resolution TAG measurements for obtaining a more complete picture of organic aerosol composition.

High-volume filter samples ( 26 in total) were collected adjacent to the TAG inlet at $9.3 \mathrm{~m}$ from 20 September-1 October 2007. The samples were collected using a Thermo Anderson Total Suspended Particulate (TSP) high volume (HiVol) sampler with an SA-230-F impaction plate at a volumetric flow of $68 \mathrm{~m}^{3} \mathrm{~h}^{-1}$, as previously described by Bench and Herckes (2004). The impaction plate removes particles with diameters larger than $2.5 \mu \mathrm{m}$. Samples were collected for between 6 and $12 \mathrm{~h}$ on a $20 \mathrm{~cm} \times 25 \mathrm{~cm}$ quartz fiber filter (Gellman QM-A). The quartz filters were pre-fired by baking at $600{ }^{\circ} \mathrm{C}$ for $12 \mathrm{~h}$ and stored in sealed plastic bags prior to use. After sampling the quartz filters were immediately placed in pre-baked aluminum foil and stored frozen until analyzed. A field blank was obtained by placing one filter in the sampler for ten minutes with the pump off on 26 September, the midpoint of the sampling period. These filters were collected during only the cold period of the campaign and are not representative of the entire campaign. Therefore, additional high-volume filter samples (17 in total including a field blank) were collected following the identical sampling protocol at the same height and on the same tower from 26 July31 July 2009 during a follow up campaign. These filters were collected when meteorological conditions were similar to the earlier part of the 2007 campaign, although there was no incidence of wildfire influence during the 2009 sampling period.

\subsubsection{Radiogenic carbon $\left({ }^{14} \mathrm{C}\right)$ analysis}

Eight of the 2007 filters, selected for their higher organic aerosol loadings, based on concurrent AMS measurements, were analyzed for their radiogenic carbon $\left({ }^{14} \mathrm{C}\right)$ content by accelerator mass spectrometry at the Lawrence Livermore National Laboratory (LLNL), as previously described by Bench and Herckes (2004). Briefly, $36 \mathrm{~cm}^{2}(6 \times 6 \mathrm{~cm}) \mathrm{sam}-$ ples were cut from the central region of each quartz filter, sealed under vacuum with copper oxide oxidizer in a quartz tube and combusted at $900^{\circ} \mathrm{C}$. Carbon dioxide from the combustion was cryogenically isolated from other combustion products and measured manometrically before conversion to graphite by hydrogen reduction using an iron catalyst. The ${ }^{14} \mathrm{C} / \mathrm{C}$ ratios in the graphite samples were measured by accelerator mass spectrometry. The data are reported as a fraction of the modern radiocarbon standard (Stuiver and Polach, 1977) and have been corrected for the nuclear bomb pulse ef- fect by dividing the fraction of modern carbon by 1.06 , to account for the additional modern carbon content in the current atmosphere (Levin et al., 2010). No correction for the contribution of biomass burning to non-fossil carbon (Aiken et al., 2010) was made because the filters were all collected during a period with no substantial biomass burning influence. The ${ }^{14} \mathrm{C}$ measurements were also corrected for isotopic fractionation effects using a $2{ }^{13} \mathrm{C}$ value of -25 per mil (Stuiver and Polach, 1977), though the magnitude of this correction was small and had a minimal effect on the radiocarbon values.

\subsubsection{Organosulfate and nitrooxyorganosulfate analysis}

Aliquots $\left(100 \mathrm{~cm}^{2}\right)$ of 15 of the filters collected between 20 September and 25 September 2007 and all 16 of the filters collected in 2009 were analyzed for organosulfates and nitrooxyorganosulfates. These filters represented two continuous five day periods, one in each year, with three filters per day that provided an uninterrupted time series with sufficient time resolution to separate the influence of local early morning biogenic emissions from the afternoon arrival of the urban plume from Sacramento and nighttime chemistry. Samples were analyzed by ultra performance liquid chromatography coupled to electrospray ionization high-resolution timeof-flight mass spectrometry (UPLC/ESI-HR-TOFMS) at the California Institute of Technology (Caltech). Identically sized aliquots of the same filters were also analyzed by high performance liquid chromatography coupled to electrospray ionization high-resolution quadrupole time-of-flight mass spectrometry (HPLC/ESI-HR-QTOFMS) at the University of Aarhus, Denmark. The analytical methodologies have previously been described by Surratt et al. (2008) (Caltech) and Kristensen and Glasius (2011) (Aarhus). Briefly, organosulfates and nitrooxyorganosulfates were detected as deprotonated ions in the negative ion mode at both institutions using reverse-phase chromatography. At Caltech concentrations were assigned from relative responses to authentic organosulfate standards derived from the epoxide of butadiene (BEPOX) and $\beta$-pinene oxide for all isoprene and monoterpene derived organosulfates, respectively. At Aarhus, camphor sulfonic acid was used as a surrogate standard for all the organosulfates.

\section{Results and discussion}

\subsection{Bulk aerosol measurements}

Figure 1a shows a stacked time series plot of aerosol components (organics, sulfate, nitrate, ammonium and chloride) as measured by the AMS. Organics were the dominant fraction $(\sim 75 \%)$ contributing on average $3 \mu \mathrm{g} \mathrm{m}^{-3}$ to the total aerosol mass. Of the inorganic components, sulfate was the most abundant contributing on average $0.6 \mu \mathrm{g} \mathrm{m}^{-3}$ to the total $(\sim 15 \%)$. Ammonium and nitrate contributed on average $0.3 \mu \mathrm{g} \mathrm{m}^{-3}(\sim 7 \%)$ and $0.2 \mu \mathrm{g} \mathrm{m}^{-3}(\sim 5 \%)$, respectively, 

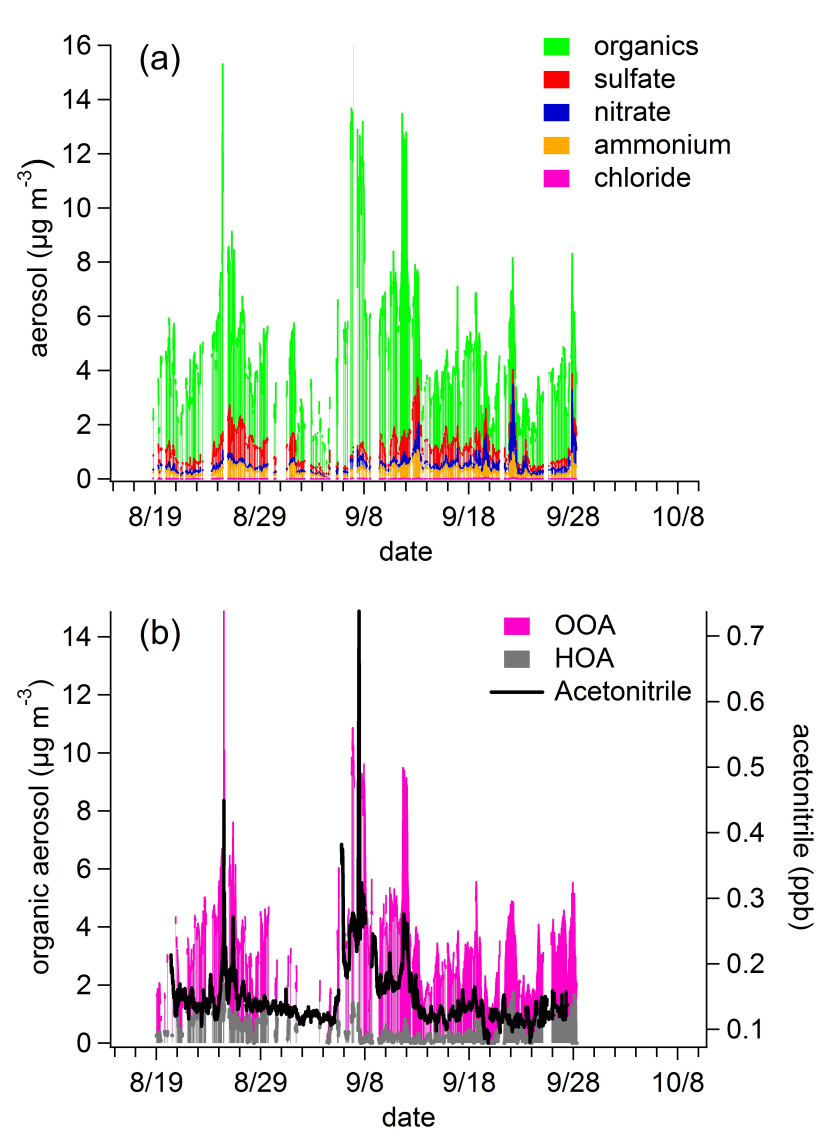

Fig. 1. (a) Bulk aerosol composition (organics, sulfate, nitrate, ammonium and chloride) as measured by the aerosol mass spectrometer (AMS), indicating the prevalence of the carbonaceous fraction. (b) Organic aerosol divided into "hydrocarbon like" (HOA) and "oxygenated" (OOA) shown along with acetonitrile, a gas phase tracer for biomass burning.

and the aerosol was approximately neutralized without excess $\mathrm{H}^{+}$(Farmer et al., 2011), indicating that the dominant form of sulfate at the site was ammonium sulfate. Refractory ions, AMS uncertainties, or external mixing are judged to contribute little uncertainty to this assessment. The ammonium sulfate at the site contrasts with the highly acidic conditions required to form organosulfates efficiently in previous laboratory experiments (Surratt et al., 2008, 2010) that require sulfate to be in the form of ammonium bisulfate or sulfuric acid. Many varieties and concentrations of organosulfates and nitrooxyorganosulfates were observed at this site (see Sect. 3.7). These species are detected by the AMS but are not distinguishable from the inorganic salts (Farmer et al., 2010). As such the observed nitrate and sulfate concentrations reported here represent the combined total of both inorganic and organic species, and are thought to be dominated by the inorganic fraction, due to the close balance with ammonium. Figure $1 \mathrm{~b}$ shows a time series plot of the AMS factors, "oxygenated" organic aerosol (OOA) and "hydrocarbon-like" organic aerosol (HOA), along with acetonitrile, a known gas phase tracer for biomass burning (de Gouw and Warneke, 2007). The OOA fraction was dominant throughout the campaign and the highest concentrations were associated with biomass burning influence at the site, as indicated by elevated acetonitrile concentrations. Grieshop et al. (2009) and Cubison et al. (2011) have recently summarized the aging of biomass burning emissions to form OOA in laboratory and field studies, respectively. Thus the increased OOA is consistent with the impact of aged biomass burning plumes. A scatter plot of OOA versus acetonitrile (Fig. S1; Supplement) shows a strong positive correlation ( $\left.R^{2}=0.67, n=273\right)$ during periods of biomass burning influence (acetonitrile $>0.175 \mathrm{ppb}$ ) (Warneke et al., 2006). However, during all other periods (acetonitrile $<0.175 \mathrm{ppb}$ ) this relationship was very poor $\left(R^{2}=0.21, n=1398\right)$ indicating that biomass burning was not an important source of OOA outside of the sporadic wildfire plumes.

\subsection{Carbonaceous aerosol: non-fossil or fossil}

Table 1 summarizes the data from the radiogenic carbon $\left({ }^{14} \mathrm{C}\right)$ analysis along with the organic carbon measured by the AMS averaged over the same time periods as the filters. The AMS data was convert from $\mu \mathrm{g} \mathrm{m}^{-3}$ to $\mu \mathrm{g} \mathrm{C} \mathrm{m}^{-3}$ using an organic matter to organic carbon (OM/OC) ratio of $2.31 \pm 0.05$ determined from an elemental analysis of the high resolution AMS data (Aiken et al., 2008). The total carbon mass loading on the $36 \mathrm{~cm}^{2}$ filter punches ranged from $300-560 \mu \mathrm{g} \mathrm{C}$, which were in some cases close to the $210 \mu \mathrm{g} \mathrm{C}$ mass on the field blank and thus involved a non-negligible blank correction. As such, analytical uncertainties were generally higher than previous publications of ${ }^{14} \mathrm{C}$ analyses. A plot of the organic carbon measured on the filters versus the AMS is shown in Fig. S2 (Supplement). There was very little variability in either of these measures of OC, which explains the lack of a stronger correlation. More importantly, the OC measured on the filter is about three times larger than the OC measured by the AMS (and the AMS was consistent with SMPS volume measurements). A small discrepancy $(\sim 20 \%)$ might be expected from the differing size cuts $\mathrm{PM}_{1}$ (AMS) vs. $\mathrm{PM}_{2.5}$ (filter OC) (Alves et al., 2000) and $30 \%$ from measurement uncertainties. Therefore, it is likely that there was gas phase adsorption into the filter during sample collection since no denuder could be used at the high flow rates necessary for the ${ }^{14} \mathrm{C}$ measurements and that at these very low OC concentrations the presence of gas phase biogenic compounds could bias the observed ${ }^{14} \mathrm{C}$ measurements. We do not have information on the ${ }^{14} \mathrm{C}$ content of the gas phase compounds adsorbed onto the filters and in the absence of this information our analysis assumes that the ${ }^{14} \mathrm{C}$ content of the adsorbed gas phase compounds was similar to that of the aerosol. On average, the non-fossil fraction was determined to be $0.84 \pm 0.19$ (mean \pm standard deviation) of the total measured aerosol carbon. This indicates the 
Table 1. Total carbon mass analysed $(\mathrm{mgC})$, aerosol loading $\left(\mathrm{PM}_{2.5} ; \mu \mathrm{g} \mathrm{Cm}^{-3}\right)$ and fraction of modern carbon determined from the radiogenic $\left({ }^{14} \mathrm{C}\right)$ carbon results. For comparison the aerosol loading $\left(\mathrm{PM}_{1} ; \mu \mathrm{g} \mathrm{C} \mathrm{m}^{-3}\right)$ from the AMS averaged onto the same timescale as the filter samples are also shown.

\begin{tabular}{|c|c|c|c|c|c|}
\hline \multirow{2}{*}{$\begin{array}{l}\text { Sampling Period } \\
\text { (MM/DD hh:mm) }\end{array}$} & \multirow{2}{*}{$\begin{array}{c}\text { Sample } \\
\text { Volume } \\
\left(\mathrm{m}^{3}\right)^{\mathrm{a}}\end{array}$} & \multirow{2}{*}{$\begin{array}{l}\text { Mass Analysed } \\
\qquad(\mu \mathrm{g} C)^{\mathrm{a}}\end{array}$} & \multicolumn{2}{|c|}{$\begin{array}{l}\text { Aerosol Loading } \\
\left(\mu \mathrm{g} \mathrm{C}^{-3}\right)^{\mathrm{b}}\end{array}$} & \multirow{2}{*}{$\begin{array}{l}\text { Fraction } \\
\text { Modern }^{b}\end{array}$} \\
\hline & & & filter & $\mathrm{AMS}^{\mathrm{c}}$ & \\
\hline field blank & 0 & $210 \pm 40$ & - & - & $<0.06$ \\
\hline 09/21 13:05-09/21 18:30 & 32.2 & $300 \pm 10$ & $2.77 \pm 1.63$ & $1.09 \pm 0.07$ & $1.21 \pm 0.39$ \\
\hline 09/21 18:45-09/22 07:15 & 74.2 & $430 \pm 10$ & $2.87 \pm 0.71$ & $1.31 \pm 0.13$ & $1.00 \pm 0.13$ \\
\hline 09/25 18:45-09/26 07:15 & 74.2 & $470 \pm 10$ & $3.46 \pm 0.71$ & $1.12 \pm 0.11$ & $0.81 \pm 0.09$ \\
\hline 09/26 07:30-09:26 16:00 & 50.3 & $390 \pm 10$ & $3.44 \pm 1.04$ & $1.00 \pm 0.12$ & $0.89 \pm 0.14$ \\
\hline 09/26 19:00-09/27 07:15 & 73.2 & $530 \pm 10$ & $4.33 \pm 0.72$ & $1.34 \pm 0.11$ & $0.76 \pm 0.07$ \\
\hline 09/27 07:30-09/27 12:50 & 32.0 & $330 \pm 10$ & $3.66 \pm 1.64$ & $0.66 \pm 0.06$ & $0.69 \pm 0.16$ \\
\hline 09/27 13:05-09/27 17:15 & 24.7 & $310 \pm 10$ & $3.80 \pm 2.12$ & $1.13 \pm 0.17$ & $0.67 \pm 0.19$ \\
\hline 09/27 17:30-09/28 07:15 & 81.6 & $560 \pm 10$ & $4.23 \pm 0.64$ & $1.34 \pm 0.30$ & $0.69 \pm 0.06$ \\
\hline
\end{tabular}

\footnotetext{
a Volume and mass correspond to $36 \mathrm{~cm}^{2}$ aliquots of each filter (total area $412 \mathrm{~cm}^{2}$ ).

$\mathrm{b}$ The aerosol loading and fraction modern data have been blank corrected.

${ }^{\mathrm{c}}$ Conversion of $\mu \mathrm{g} \mathrm{m}^{-3}$ to $\mu \mathrm{g} \mathrm{C} \mathrm{m}{ }^{-3}$ using an OM/OC ratio of $2.31 \pm 0.05$ determined from an elemental analysis of the high resolution AMS data.
}

likely importance of non-fossil (a major fraction of which is presumably biogenic) carbon to the total carbonaceous aerosol at the Blodgett site. It is likely that this also includes non-negligible contributions from non-fossil urban sources, which can roughly be estimated as follows: the fossil fraction is 0.16 and by assuming urban emissions were $10-50 \%$ nonfossil (Hildemann et al., 1994; Hodzic et al., 2010b), then $(0.1 / 0.9) \times 0.16=0.02$ and $(0.5 / 0.5) \times 0.16=0.16$ so a range of 0.02-0.16 likely represents the non-fossil urban fraction. Therefore, if $0.02-0.16$ of the 0.84 is from pollution sources, then $0.68-0.82$ remains that is presumably from biogenic sources.

\subsection{Relationship between organic aerosol and anthropogenic tracers}

A strong positive relationship was observed between OA and 2-propyl nitrate (Fig. 2a), similar to previous studies (de Gouw et al., 2005; Weber et al., 2007). The BEARPEX data in this figure have been color coded by acetonitrile and in the absence of biomass burning influence (i.e. acetonitrile $<0.175 \mathrm{ppbv}$ ) there is very good agreement between the BEARPEX and New England Air Quality Study (NEAQS) data (de Gouw et al., 2005). The meteorological dynamics at the Blodgett site may introduce misleading correlations between advected and photochemical sources as air from the Central Valley generally arrives around the same time as the local maximum in photochemical products. It may be possible to filter out this interference by looking at the same correlation for specific times of day, e.g. early morning (07:00-09:00), midday (12:00-14:00) and early evening (19:00-21:00). Figure $2 b$ shows that the correlation for these three selected time periods are all strong positive relation- ships with identical slopes, within the uncertainties of the fits, as the entire dataset giving us confidence that this relationship results from chemistry and is not caused by similar transport pathways. The slope between OA and 2-propyl nitrate correlations was $20 \%$ lower during BEARPEX compared to NEAQS (de Gouw et al., 2005) indicating that SOA production may have been slightly less efficient in the 2007 Sacramento plume relative to 2002 New York plume.

OA was also correlated to $\mathrm{CO}$ (Fig. 3), which is again consistent with previous measurements (Bahreini et al., 2009; Sullivan et al., 2006; Weber et al., 2007). The CO data has been filtered for acetonitrile $>0.175 \mathrm{ppb}$ to remove influence from biomass burning, as this is known to be an important source of CO (Andreae and Merlet, 2001). The CO data in this figure have also been filtered by wind speeds $<1 \mathrm{~m} \mathrm{~s}^{-1}$ to remove the sporadic influence of the onsite generator. $\mathrm{CO}$ is a combustion tracer, so in the absence of biomass burning, a correlation to OA indicates a relationship between anthropogenic derived emissions from combustion sources to OA. However, $\mathrm{CO}$ can also be produced from the oxidation of anthropogenic and biogenic hydrocarbons. Chemical production of $\mathrm{CO}$ from the oxidation of anthropogenic VOCs is thought to be negligible (compared to the direct combustion emissions of $\mathrm{CO}$ ) within these timescales (Griffin et al., 2007). Conversely, chemical production of CO from biogenic VOCs is likely non-negligible, e.g. Hudman et al. (2008) reported that the source of CO in the Southeast US during summer was dominated by BVOC oxidation although this analysis has not been done for our site. Slowik et al. (2010) estimated in Eastern Canada that a large contribution of biogenic $\mathrm{CO}\left(\sim 100 \mathrm{ppbv}\right.$ for $\sim 15 \mathrm{ug} \mathrm{m}^{-3}$ of OA $)$ derived from terpene oxidation although this was for a period when biogenic emissions where aged over many days 

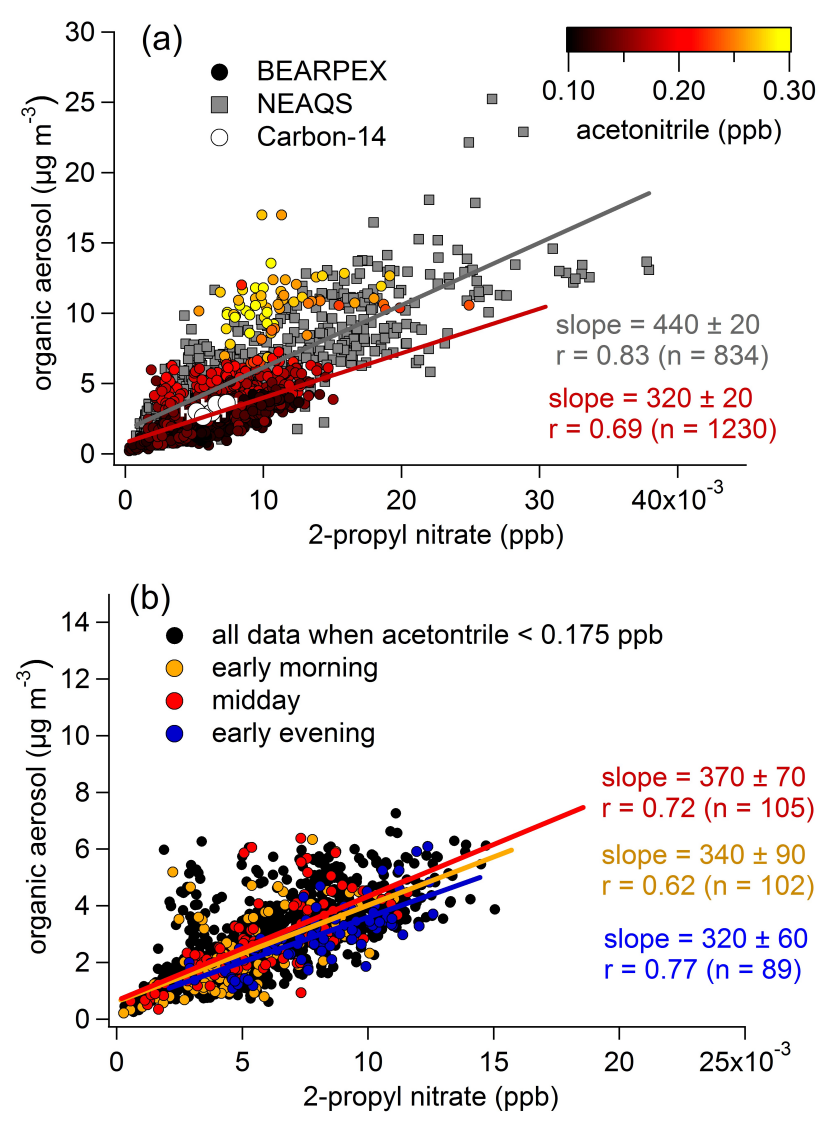

Fig. 2. (a) Scatter plot of organic aerosol (OA) versus 2-propyl nitrate for BEARPEX (this work; black circles) and the New England air quality study (NEAQS (de Gouw et al., 2005); grey squares). The radiogenic carbon $\left({ }^{14} \mathrm{C}\right)$ data is shown as filled white squares and the BEARPEX data is color coded by acetonitrile to show that the $14 \mathrm{C}$ sampling period was not influenced by biomass burning. (b) Scatter plot of OA vs. 2-propyl nitrate filtered by acetonitrile $(<0.2 \mathrm{ppb})$ and separated into three time periods; early morning (07:00-09:00; orange circles), midday (12:00-14:00; red circles) and early evening (19:00-21:00; blue circles).

prior to impacting their site. In contrast to Eastern Canada, Blodgett forest is dominated by isoprene emissions, which are partially oxidized on arrival at the site following approximately three hours of photochemical processing. If we assume that all the formaldehyde generated in the first few hours of isoprene oxidation yields $\mathrm{CO}$ then we can derive an upper limit for the contribution of biogenic $\mathrm{CO}$ to the total observed CO. In chamber experiments of isoprene oxidation, formaldehyde was observed after several hours with a yield of $\sim 160 \%$ (Lee et al., 2006), which would give an upper limit of $<5 \mathrm{ppb}$ of biogenic CO. This is small relative to the observed enhancement (on average $\sim 50 \mathrm{ppb}$ ) and implies that the majority of the $\mathrm{CO}$ observed at the site is not biogenic in origin. $\mathrm{CO}$ was also well correlated to isopentane (Fig. S3; Supplement). The upwind source region ratio of

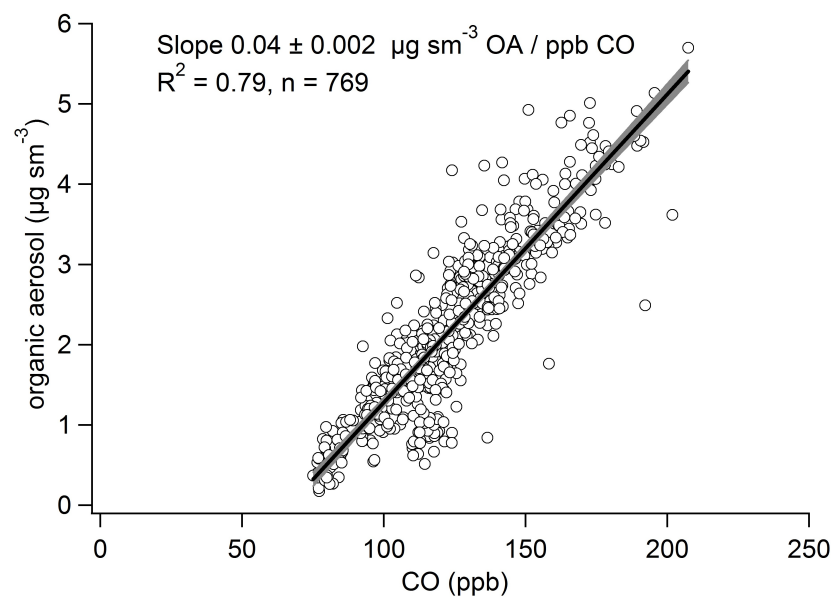

Fig. 3. Correlation of CO to organic aerosol (OA) during both meterological periods at BEARPEX. The OA data was filtered for acetonitrile $>0.175 \mathrm{ppb}$ to remove the influence of biomass burning sources of OA. The CO data was filtered by windspeeds $>1 \mathrm{~m} \mathrm{~s}^{-1}$ to remove generator spikes that influenced the site under stagnant conditions. The OA data has been converted to $\mu \mathrm{g} \mathrm{sm}^{-3}$ (at $273 \mathrm{~K}$ and $1 \mathrm{~atm}$ ) for consistency with previous studies (Cubison et al., 2011; DeCarlo et al., 2010).

isopentane to $\mathrm{CO}$ was calculated from isopentane measurements made in the summer of 2001 at Granite Bay and from $\mathrm{CO}$ measurements from the California Air Resources Board Del Paso Manor monitoring station (http://www.arb.ca.gov/ aqd/aqded/aqdeddld.htm) (see Murphy et al., 2007) and is shown in Fig. S4. A lower ratio of isopentane to $\mathrm{CO}$ would be expected downwind due to differing atmospheric loss rates (isopentane $k_{\mathrm{OH}}=3.6 \times 10^{-12} \mathrm{~cm}^{3}$ molecules ${ }^{-1} \mathrm{~s}^{-1}$ versus $\mathrm{CO} k_{\mathrm{OH}}=1.4 \times 10^{-13} \mathrm{~cm}^{3}$ molecules ${ }^{-1} \mathrm{~s}^{-1}$ at $298 \mathrm{~K}$ ) (Atkinson and Arey, 2003; Atkinson et al., 2006) and atmospheric dilution during advection from the Central Valley to the Blodgett site. Dillon et al. (2002) showed that at the peak impact of the urban plume the air at Blodgett Forest was characterized as a mixture of $\sim 32 \%$ from the urban core and $\sim 68 \%$ from the relatively clean background. They also reported an average daytime $\mathrm{OH}$ concentration of $1 \times 10^{7}$ molecules $\mathrm{cm}^{-3}$ for the transect between Sacramento and Blodgett in 2001. The best fit trend to the 2007 data presented here was with an $\mathrm{OH}$ concentration slightly lower than that reported by Dillon et al. (2002), which would be expected considering the substantial decreases in $\mathrm{NO}_{\mathrm{x}}$ emission in this region between 2001 and 2007 (LaFranchi et al., 2011). The absence of large deviations from this correlation supports the suggestion that biogenic sources of $\mathrm{CO}$ at Blodgett were small. The observed correlation between $\mathrm{CO}$ and $\mathrm{OA}$ at Blodgett Forest indicates a possible coupling between $\mathrm{SOA}$ and something emitted concurrently to combustion derived $\mathrm{CO}$, e.g. $\mathrm{NO}_{\mathrm{x}}$ and/or $\mathrm{SO}_{2}$. 


\subsection{Diurnal variations in organic aerosol and gas phase tracers}

As a result of strong orographic forcing, the daily pattern of winds impacting the Blodgett Forest site are nearly constant in speed and direction (Day et al., 2009; Murphy et al., 2006), and as a result, averaged daily profiles are highly representative of diurnal behavior at this site. Figure 4 shows the average diurnal profiles for organic aerosol (OA), isopentane, $\alpha$-pinene and the sum of methyl vinyl ketone (MVK) and methacrolein (MACR) for the two different meteorological periods (hot and cold) as defined in Sect. 2.1.

Isopentane is a tracer for urban influence as it is known to be emitted from both vehicle exhaust and evaporation of gasoline fuel (Gentner et al., 2009). Mixing ratios of isopentane ranged from $0.03-0.09 \mathrm{ppb}$ and $0.03-0.05 \mathrm{ppb}$ in the hot and cold periods, respectively. Mixing ratios generally increased throughout the day during both meteorological periods, illustrating the transport of urban pollution from Sacramento and the Central Valley, which reaches a maximum late in the day. Differences between the hot and cold periods likely reflect differences in the contributions of evaporative emissions from gasoline and/or changes in the efficiency of transport from the Central Valley to Blodgett Forest. MVK and MACR are the major first generation products from the atmospheric oxidation of isoprene (Pierotti et al., 1990). Mixing ratios of MVK + MACR are lowest in the morning and then increase sharply with a maximum just after noon, reflecting the transport and oxidation of isoprene emissions from a $30-\mathrm{km}$ wide band of oak trees located on the foothills, several hours upwind of the Blodgett site (Dreyfus et al., 2002). Identical diurnal variations are observed during both periods, although observed mixing ratios are a factor of $\sim 6$ lower during the cold period as a result of reduced isoprene concentrations caused by the strong temperature and light dependence of its emission (Guenther et al., 1993). $\alpha$-pinene is a monoterpene known to be emitted locally from the vegetation present at the site (Schade et al., 1999; Bouvier-Brown et al., 2007, 2009a) and shows two maxima. Emissions are highest during the day as driven by temperature, but the concentrations are highest at night due to accumulation in the shallow nocturnal boundary layer at low wind speeds, with maxima occurring when the wind stagnates during the shifts from downslope to upslope flow (early morning) or upslope to downslope flow (early evening). Other locally emitted biogenic compounds, e.g. 2-methyl-3-buten-2-ol (MBO) (Schade and Goldstein, 2001) and methyl chavicol (BouvierBrown et al., 2009b), also exhibit this behavior, but concentrations of these compounds which are also emitted as a function of light are generally lower at night than during the day. These features are observed in both meteorological periods although the magnitude for $\alpha$-pinene is, on average, a factor of $\sim 3$ lower during the cold period while methyl chavicol was about the same during both periods (Fig. 5). Monoterpene emissions have been reported to be dependent on rel-

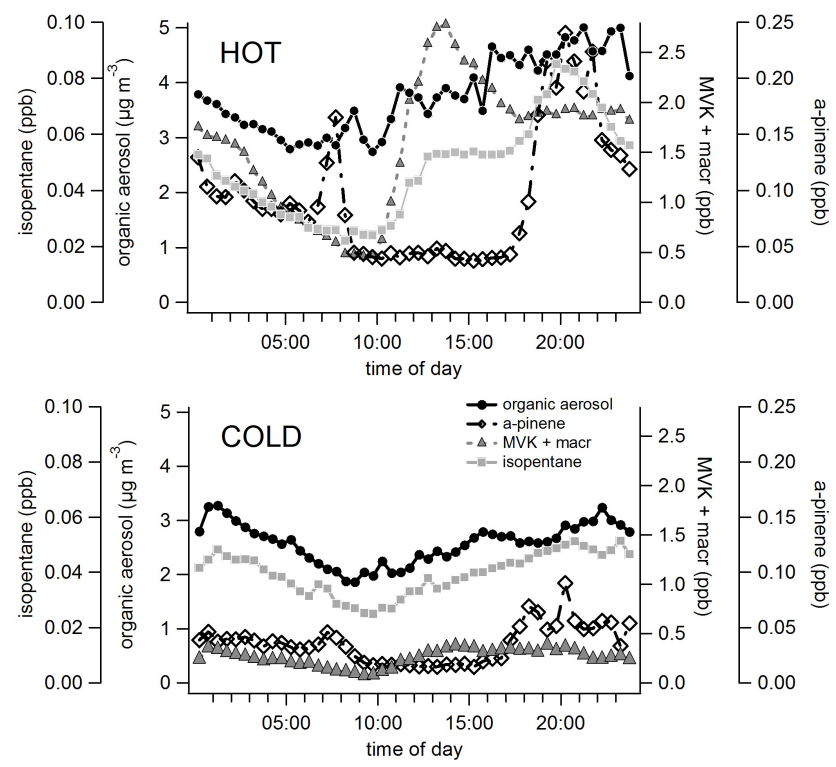

Fig. 4. Comparison of the diurnal variation of organic aerosol (OA), sum of methyl vinyl ketone and methacrolein (MVK + MACR), $\alpha$ pinene and isopentane, separated into the two meteorological periods; hot (top panel) and cold (bottom panel).

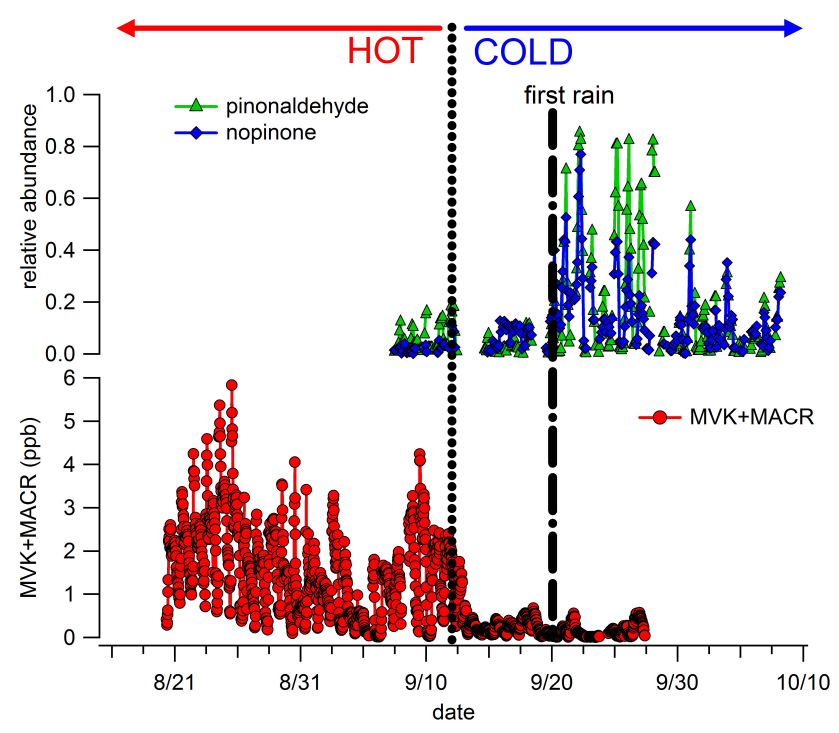

Fig. 5. Time series plots of the sum of methyl vinyl ketone and methacrolein (MVK + MACR) and particle phase biogenic oxidation tracers pinonaldehyde and nopinone as measured by TAG showing their varying behavior during the hot and cold periods and following the first rains in early fall.

ative humidity (Schade et al., 1999) and concentrations of several monoterpenes were observed to increase following the first rain events on 20 September (Bouvier-Brown et al., 2009a). However, these concentrations were still lower than those during the hot period. Methyl chavicol concentrations were also reported to respond to rain although there was a 
delay of several days relative to the monoterpenes (BouvierBrown et al., 2009b).

In contrast to the gas-phase tracers shown in Fig. 4, the diurnally averaged OA concentrations changed by less than a factor of 2 throughout the day during both the hot and cold periods, which may temper the statement that most of the OA is derived from biogenic sources. However, as we will show in this paper there are multiple components to BSOA whose contributions change not only diurnally but also seasonally. Additionally, the fraction of oxidation products that become incorporated into the aerosol phase may be dependent on more factors than simply the emission rate of the precursors. Figure 5 shows how the MVK + MACR concentrations, a proxy for isoprene oxidation products, decline sharply from the hot to the cold periods and that their abundances are not affected by the onset of rain in mid-September. As will be shown in Sect. 3.7 this is generally consistent with the behavior of the isoprene-derived organosulfates whose concentrations were higher during hotter conditions. Figure 5 also shows how the abundance of two particle-phase tracers of terpene oxidation, pinonaldehyde and nopinone derived from $\alpha$-pinene and $\beta$-pinene, respectively (these compounds are likely present as particle phase oligomers, see Sect. 3.6), increase by more than a factor of 5 following the first rain event and remain elevated for more than a week. As a result the observed OA is a superposition of contributions that maximize during both day and night and are influenced by not only the emission rate of the precursor compounds, but also by additional factors that may control the uptake of the oxidation products into the aerosol phase. One such factor could be the availability of liquid water in the aerosol phase that may, for example, be important in facilitating the gem-diol reactions between carbonyl compounds that has been speculated to result in the formation of low vapor pressure oligomeric products (Gao et al., 2004). Isoprene oxidation products appear to be a dominant component of BSOA during the hot period when emissions of isoprene are the largest, while during the cold period terpene oxidation products are a more substantial contributor to BSOA. Other particle-phase molecular markers also show large changes in their abundances by factors of 2-20 (Fig. 6) indicating that sources of OA were changing both throughout the day and as the season progressed from summer into fall.

\subsection{In situ particle phase molecular markers}

The particle phase molecular marker compounds measured by the TAG instrument in $\mathrm{PM}_{2.5}$ were predominately secondary in nature (or their decomposition products, see below) consistent with the predominance of the oxygenated organic aerosol (OOA) fraction $(\sim 85 \%)$ as determined from AMS measurements. In total, 65 individual compounds were detected and continuously tracked by TAG. Species identification was either by retention time matching to known standards or from mass spectral matching to a commercially available library of mass spectra (NIST 2008); more than $80 \%$ of the detected peaks were identified. To determine the contribution of gas phase adsorption to the surfaces heated during the thermal desorption cycle the air flow was alternated between two separate paths, one with a teflon filter (Zefluor $2.0 \mu \mathrm{m}$, Pall Corp.) inline to remove particles. This so called "filtered ambient" run can be subtracted from the "ambient" run to give particle phase signals (i.e. particle phase $=$ ambient - filtered ambient) to produce relative abundance particle phase timelines for each compound.

Similar to previous work (Williams et al., 2007, 2010b) compounds that did not match specific criteria were removed prior to performing a factor analysis. In this work the criteria applied were that compounds must be less than $30 \%$ in the gas phase to avoid large subtractions and each compound's particle-phase timeline must have a coefficient of determination $(R)>0.7$ with its ambient (gas + particle) timeline indicating that most of the variability was conserved after subtracting the gas-phase portion. Also, compounds that were below the detection limits for more than $30 \%$ of the study have been removed to maximize the number of data points, leaving a total of 21 individual compounds. Additionally, 19 gas phase compounds and the total OA measured by the AMS were also included in the factor analysis. A complete list of all compounds including molecular formulas and an estimate of uncertainty in compound identification are given in Table 2. Factor analysis was performed in SPLUS 6.2 (MathSoft, Inc.), using varimax rotation and principal factors extraction, similar to previous work (Williams et al., 2007). The input parameters fit best to 6 different factors that accounted for $84 \%$ of the variance and that can be thought of as signatures of specific sources or transformation processes (Table 2). Additional factors individually explained less than $2 \%$ of the variance, or less than half of the smallest contributing factor, and therefore were not included in the analysis.

Four of the factors had both particle phase and gas phase compounds loading on them. Figure 6 shows the temporal and diurnal trends of four major particle phase tracers (phthalic acid, levoglucosenone, pinonaldehyde and methyl chavicol), during both meteorological periods. These represent four of the six factors or sources identified from the factor analysis (Table 2). We observe the same number of factors as for a similar analysis for gas-phase only species by Lamanna and Goldstein (1999) for the same site. While the identified sources were not identical there were strong similarities between the identified factors in this work and in Lamanna and Goldstein (1999). The general source categories; anthropogenic and biomass burning emissions, temperature-dependent biogenic emissions and temperatureand light-driven biogenic emissions, were consistent between the two analyses. It is important to note that isoprene oxidation products, e.g. the methyl tetrols, have previously been observed in the particle phase at the site (Cahill et al., 2006), although as a result of their high polarity are not observable with TAG. As a result there were no good tracers 
Table 2. Molecular marker compounds (particle phase compounds measured by TAG highlighted by gray shading) used in the factor analysis. Factor 1 (F1) aged biomass burning and oxidized urban emissions, Factor 2 (F2) oxidized urban emissions, Factor 3 (F3) oxidation products of temperature-driven local biogenic emission, Factor 4 (F4) monoterpene emissions, Factor 5 (F5) anthropogenic emissions and Factor 6 (F6) Local methyl chavicol emissions and oxidation. Factor analysis was performed in SPLUS 6.2 (MathSoft Inc.), using varimax rotation and principal factors extraction. The model was limited to three factors because additional factors had very low sum square loadings and did not explain any substantial portion of the variance. Proportion variance defines the fraction of the data explained by each factor. Uncertainty of compound identification is divided into three categories (i.e. low, medium and high); high uncertainty for compounds which could not be identified from mass spectral library matches or from known standards, medium uncertainty for compounds with better matches and low uncertainty for compounds with very good library matches and that could be confirmed by retention time matching to authentic standards.

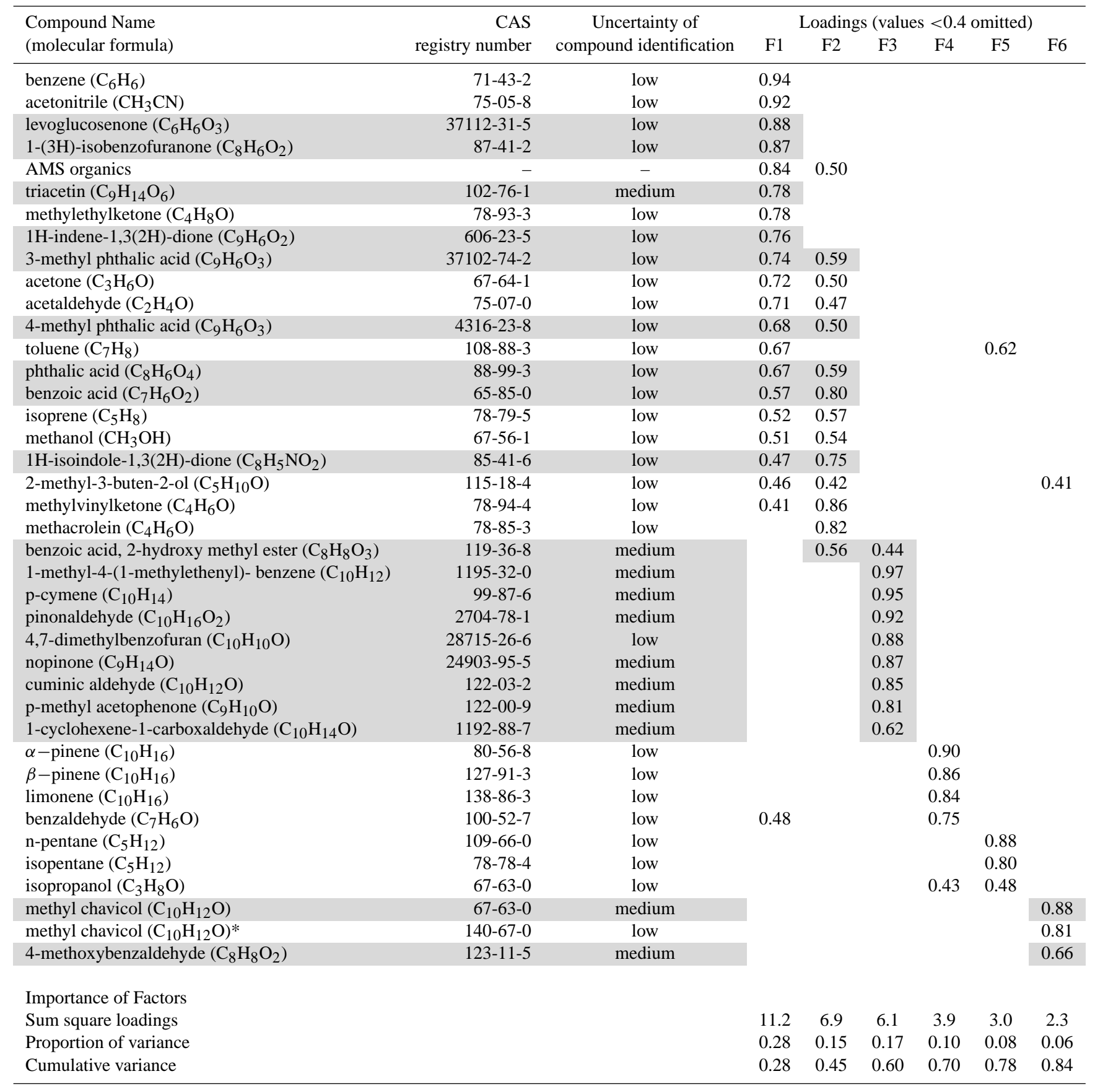

* The gas phase methyl chavicol data was measured at two heights during the campaign $1.5 \mathrm{~m}$ (20 August-12 September) and $9.3 \mathrm{~m}$ (13 September-10 October) (Bouvier-Brown et al., 2009b). The $1.5 \mathrm{~m}$ data was corrected to be consistent with the $9.3 \mathrm{~m}$ data using PTR-MS canopy gradient measurements made over the same time period. 

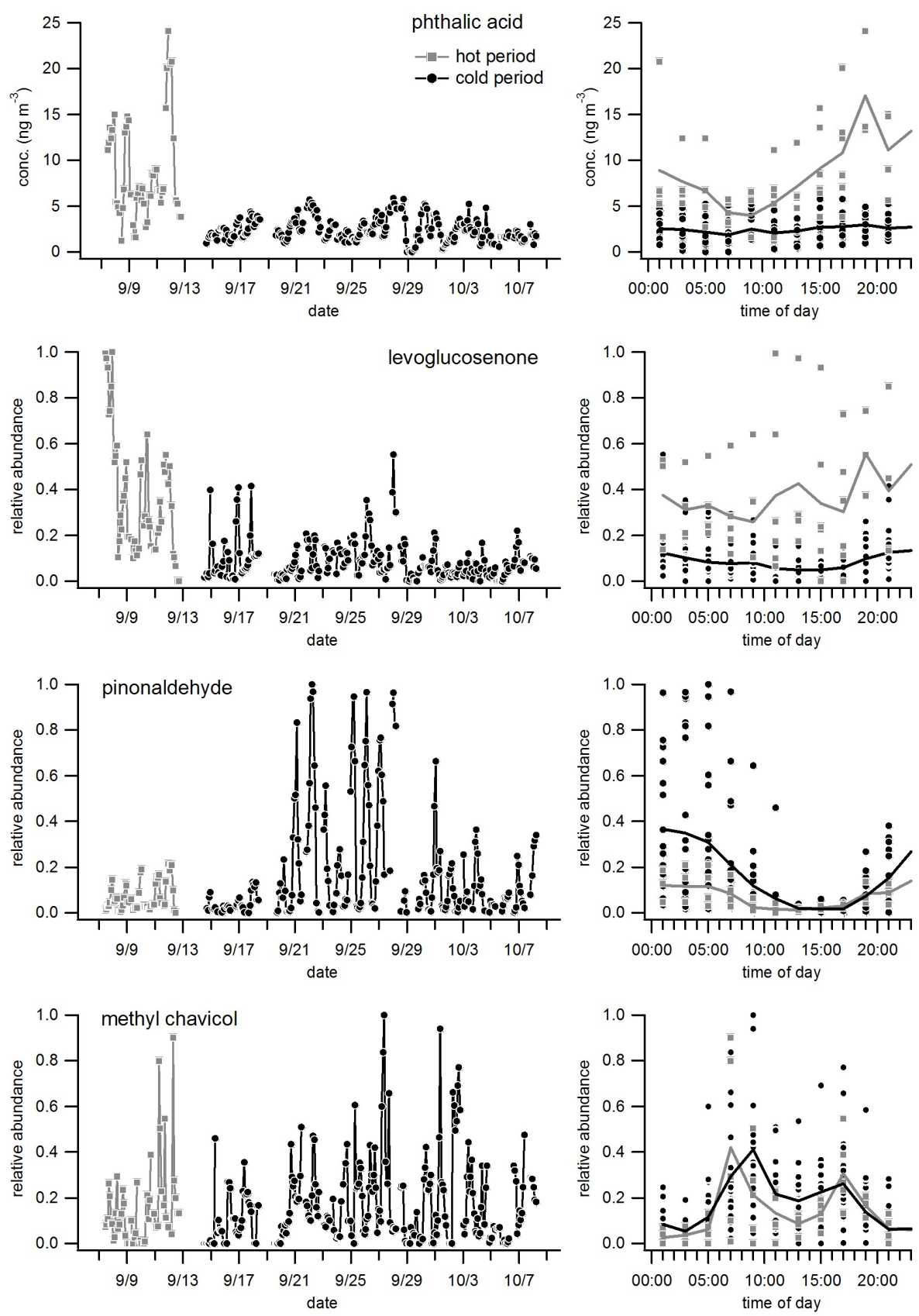

Fig. 6. Temporal and diurnal variations for the four major particle phase tracer compounds $(1,2-$ phthalic acid; 1 - levoglucosenone; 3 - pinonaldehyde; 6 - methyl chavicol) that represent four of the six sources ( 1 - aged biomass burning emissions and oxidized urban emissions, 2 - oxidized urban emissions 3 - oxidation products of monoterpene emissions, and 6 - local methyl chavicol emissions and oxidation products), identified from a factor analysis, that impacted the site during both the identified meteorological periods.

of isoprene SOA in the TAG dataset, which clearly impacts any source apportionment approach because isoprene and its oxidation products are likely an important source at the site. Several organosulfate and nitrooxyorganosulfate products of isoprene oxidation were detected following the analysis of high-volume filter samples and will be discussed further in Sect. 3.7.

\subsubsection{Factor 1: aged biomass burning and oxidized urban emissions}

This factor accounted for $\sim 28 \%$ of the variance and included a mixture of compounds that likely represent aged biomass burning emissions and oxidized urban emissions. Particle phase compounds loading onto this factor included 
phthalic acid and 3-methyl and 4-methyl phthalic acids, benzoic acid, levoglucosenone and three aromatic ketones $(1 \mathrm{H}-$ isoindole-1,3-(2H)-dione, 1H-indene-1,3-(2H)-dione and 1$(3 \mathrm{H})$-isobenzofuranone). Gas phase compounds loading substantially onto this factor were benzene, acetone, methyl ethyl ketone and acetonitrile. The high loadings of levoglucosenone and acetonitrile indicated the importance of biomass burning to this factor at the end of the hot period. Levoglucosan, a known biomass burning marker (Simoneit et al., 1999), was not detected during BEARPEX and was likely below the detection limit of the instrument. Williams et al. (2010b) also reported levoglucosenone in the absence of levoglucosan in Riverside, California and reported that levoglucosenone was associated with the identified SOA factors as well as the identified biomass burning factor (Fig. 6 of Williams et al., 2010b), suggesting that its presence in the aerosol was likely related to a combination of atmospheric processing of biomass burning and direct emission. Levoglucosenone has been reported to form from levoglucosan through dehydration and isomerisation reactions during the pyrolysis of cellulose (Lin et al., 2009). As such, it is not possible to rule out direct emission from biomass burning as a source of levoglucosenone. However, it seems likely that levoglucosenone is predominantly an oxidation product of levoglucosan, which would support the aged influence of this source. Ma and Hays (2008) reported the observation of $1 \mathrm{H}$-isoindole-1,3-(2H)-dione in aerosols emitted from agricultural fires. There were no clear diurnal variations in either of these markers consistent with the sporadic nature of biomass burning influence. However, the highest concentrations were observed in the afternoon, indicating the importance of upslope flow conditions for bringing aged fire plumes to Blodgett Forest during these events.

Phthalic acid is formed from the rapid particle-phase hydrolysis of phthalic anhydride that is a major product from the photooxidation of naphthalene under both high- and low$\mathrm{NO}_{\mathrm{x}}$ conditions (Wang et al., 2007; Kautzman et al., 2010). Napthalene is emitted directly from diesel exhaust (Rhead and Pemberton, 1996) and biomass burning (Jenkins et al., 1996). Phthalic acid is reportedly found in high concentrations in the atmosphere and has been suggested as a singlespecies surrogate for the contribution of anthropogenic SOA to ambient aerosol (Rogge et al., 1996; Schauer et al., 1996; Fine et al., 2004), making it a potentially important marker compound. Williams et al. (2010b) recently observed that out of a wide range of oxygenated molecular marker compounds, phthalic acid had the highest correlation with total SOA in an urban setting. OA, as measured by the AMS, also loaded strongly into this factor indicating the importance of the contribution of SOA to the total OA, which is consistent with the predominance of OOA. Higher phthalic acid concentrations were also associated with high mixing ratios of acetonitrile implying that biomass burning was likely an important source of SOA precursors during some periods. Interestingly, there is a clear absence of primary anthropogenic or biomass burning species (e.g. polyaromatic hydrocarbons and straight chain alkanes) in the aerosol phase and this factor is dominated by secondary compounds that are strongly correlated to OOA. TAG is sensitive to these primary nonpolar compounds (Kreisberg et al., 2009) so their absence suggests that they have been photochemically aged to levels below the instrumental detection limit.

\subsubsection{Factor 2: oxidized urban emissions}

This factor accounted for $\sim 15 \%$ of the variance and included most of the same compounds that loaded into factor 1 with the exception of the biomass burning markers, levoglucosenone and acetonitrile, which were absent from this factor. OA from the AMS measurements also loaded into this factor, again consistent with the substantial contribution of SOA to OA.

\subsubsection{Factor 3: oxidation products of monoterpene emissions}

The third factor accounted for $\sim 17 \%$ of the variance and only particle phase compounds loading onto this factor. They were a combination of monoterpene oxidation products (pinonaldehyde and nopinone), a monoterpene ( $p$-cymene) and several other oxygenated terpenoids. This factor showed a very clear diurnal variation with maxima in the early hours of the morning and was slightly offset from the maximum in temperature driven monoterpene emissions (Bouvier-Brown et al., 2009a) suggesting either nighttime oxidation in the canopy or transport of oxidized aged biogenic emissions during nighttime down slope flow. Observations of elevated pinonaldehyde concentrations at night were consistent with earlier measurements at the site in 2005 based on analysis of filters (Cahill et al., 2006). The magnitude of the diurnal profile was much larger during the later cold period indicating the importance of this source during the later part of the campaign. The AMS organics did not load significantly onto this factor indicating the particle phase tracers loading here were varying at a time when the total OA was not changing very much suggesting that this factor was not a large contributor to OA.

\subsubsection{Factor 4: monoterpene emissions}

All the terpenes included in the factor analysis loaded onto this factor which accounted for $\sim 10 \%$ of the variance. The diurnal variation of $\alpha$-pinene (Fig. 4) was representative of this factor and showed the highest concentrations at night when continuing temperature driven emissions accumulated into a shallow boundary layer due to weak vertical mixing. The lowest concentrations were during daytime when vertical mixing was the strongest. This factor compared well with the "temperature (not light) dependent biogenic emissions" factor identified by Lamanna and Goldstein (1999). 


\subsubsection{Factor 5: anthropogenic emissions}

Only the gas phase compounds isopentane, n-pentane, toluene loaded substantially into this factor which accounted for $\sim 8 \%$ of the variance. The temporal pattern of isopentane (Fig. 4) was representative of this group and showed increasing concentrations throughout the day maximising in the late afternoon consistent with transport of primary pollution from the Central Valley below. This factor compared well to the "anthropogenic emissions" factor reported by Lamanna and Goldstein (1999).

\subsubsection{Factor 6: local methyl chavicol emissions and oxidation}

The fourth factor included local methyl chavicol emissions and oxidation and accounted for $\sim 6 \%$ of the variance. Particle phase methyl chavicol and its oxidation product 4methoxy benzaldehyde (Bouvier-Brown et al., 2009b) loaded onto this factor along with gas phase methyl chavicol and 2-methyl-3-buten-2-ol (MBO). This factor showed a diurnal profile with a sharp early morning maximum characteristic of light driven emissions into a shallow boundary layer. This behavior was observed to be of similar intensity between both meteorological periods indicating that the contribution from this source was fairly consistent throughout the measurement period. However, similar to factor 3 the AMS organics did not load onto this factor suggesting that it was not a large contributor to OA.

\subsection{Observation of high vapor pressure products in the particle phase}

Previous laboratory work (Tobias et al., 2000) has shown that GC/MS measurements of particulate organic species can be affected by thermal decomposition artifacts for thermally labile species. However, this does not limit their value as tracers of sources provided their thermal decomposition is reproducible with time. At Blodgett, several compounds with very high vapor pressures (e.g. pinonaldehyde) were detected in the particle phase by TAG. Previously it has been reported (Hallquist et al., 1997; Odum et al., 1996) that pinonaldehyde is not thought to contribute to organic aerosol as result of its high vapor pressure. Pinonaldehyde has a subcooled liquid vapor pressure of 5.1 Pa at $298 \mathrm{~K}$ (Hallquist et al., 1997), corresponding to $c^{*}=2.7 \times 10^{5} \mu \mathrm{g} \mathrm{m}^{-3}$, or about $10^{4}$ times too volatile for appreciable partitioning to the OA phase under the conditions of our study. Previous work on the molecular speciation of SOA has similarly reported of species in the particle phase whose vapor pressures are too high to support substantial partitioning from the gas phase (Forstner et al., 1997a, b; Yu et al., 1998, 1999a, b).

These high vapor pressure compounds were most likely not collected as such, but are decomposition products of species with lower vapor pressures, e.g. oligomers or other
high-MW constituents like organosulfates. They were all identified by matching mass spectra to the library and matches were very good $(>80 \%)$, similar to the matches obtained from authentic standards, providing confidence in their assignments. These compounds spanned a wide variety of functionalities including hydrocarbons (e.g. 1-methyl4-(1-methylethenyl)-benzene), aldehydes (e.g. cuminic aldehyde), ketones (e.g. nopinone) and multifunctional compounds (e.g. pinonaldehyde and methyl chavicol) and were not detected in substantial quantities during filtered ambient runs when a teflon filter was switched into the sampling line (e.g. pinonaldehyde; Fig. 7). This indicated that their presence was not the result of gas-phase condensation to possible adsorption sites in the collection cell. Additionally, two of these compounds (nopinone and methyl chavicol) could not be detected when injecting known liquid standards even at high mass loadings ( $>50 \mathrm{ng}$ ) suggesting that the actual compounds were indeed evaporating very quickly, and that the observed compounds were most likely evolved from the particle phase during the thermal desorption or gaschromatographic analysis cycle.

The presence of oligomeric material in the aerosols observed at Blodgett is very likely since oligomerization has been reported in chamber studies of terpene oxidation (e.g. $\alpha$-pinene ozonolysis) (Tolocka et al., 2004; Gao et al., 2004). Recently, Hall and Johnston (2011) reported that oligomers accounted for about $50 \%$ of the mass in SOA from $\alpha$-pinene ozonolysis. It has been suggested that oligomerization takes place through aldol condensation and/or gem diol reactions following the formation of aldehydes from terpene ozonolysis (Gao et al., 2004; Tolocka et al., 2004) and an ion consistent with the dimer of pinonaldehyde has been detected in ambient aerosols (Tolocka et al., 2004). Müller et al. (2008) showed that during the ozonylsis of $\alpha$-pinene oligomers could also form through organic esterfication reactions. Another possibility would be the hydrolysis of a carbonyl compound to give a diol product (Jang et al., 2002) that has a substantially lower vapor pressure. This reaction could be reversible following dehydration during thermal desorption re-liberating the original compound into the gas phase. Higher concentrations of pinonaldehyde were detected in the particle phase following the first rain event in September when relative humidities were observed to remain consistently higher, lending support to this hypothesis.

\subsection{Organosulfate and nitroxyorganosulfate measurements}

In total, more than 50 individual organosulfate and nitroxyorganosulfate compounds were detected and identified in high volume filter samples from both 2007 and 2009 and 16 of these compounds were quantified. In total, these 16 compounds contributed, on average, $<1 \%$ to the OA mass. This minor contribution maybe as a result of the neutralized aerosol at the site or because only a small number of 


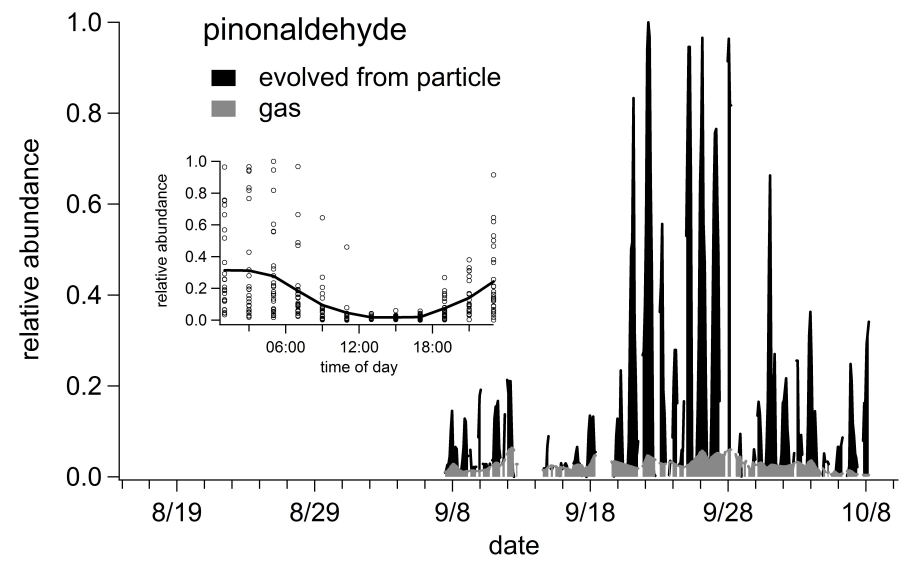

Fig. 7. Time series plot of the fraction of pinonaldehyde in the gas and particle phases, according to TAG measurements, for the entire campaign showing that the observation of pinonaldehyde was not the result of a gas phase collection artifact. The diurnal variation of pinonaldehyde for the entire campaign (inset) showing the predominance of higher abundances at night.

organosulfates were quantified due to a lack of authectic standards. Further work describing the full set of organosulfate compounds will be presented in a forthcoming publication (Worton et al., 2011). Here we focus on only two important components that serve as markers for chemical mechanisms that lead to the incorporation of BVOCs into the particle phase. These compounds were two isomers of a five carbon triol sulfate ester formed from the reactive uptake of the recently identified dihydroxy epoxides of isoprene (IEPOX) (Paulot et al., 2009) with molecular weights (MW) of 215 (Surratt et al., 2010), and three isomers of a nitrooxy sulfate ester formed from $\alpha$-pinene oxidation (MW 295) (Surratt et al., 2008). The IEPOX-derived organosulfate isomers are not chromatographically resolved and are therefore reported here as a combined total. The three $\alpha$-pinene-derived nitrooxy sulfate ester isomers are chromatographically resolved by liquid chromatography but are also reported as a sum because it was not possible to identify which peak corresponded to which isomer due to a lack of individual authentic standards.

An intercomparison of the IEPOX-derived organosulfate measured at both Caltech and the University of Aarhus from independent solvent extractions of different aliquots of the same filters from 2007 (cold) and 2009 (hot) is shown in Fig. S4 (Supplement). The correlation between the measurements was very good but the Caltech measurements are on average a factor of four higher. We believe this is due to a calibration difference resulting from the use of different standard compounds; an organosulfate of a dihydroxy epoxide of butadiene (BEPOX) was used at Caltech while camphor sulfonic acid was used at the University of Aarhus. It is known that the efficiency of electrospray ionization is structurally dependent (Kebarle, 2000) and as such the correct choice of standard is of critical importance. Due to the structural similarity of the standards used by Caltech, we expected these calibrated values to be the most appropriate and will discuss those data only from this point forwards.

Figure 8 shows time series plots of the IEPOX-derived organosulfates and the $\alpha$-pinene-derived nitrooxy organosulfates for both filter collection periods, labeled as "hot" (top panel) and "cold" (bottom panel). It is important to note that the y-axis scale offset is a factor of six smaller between the "hot" and "cold" data for the IEPOX organosulfates. In general, concentrations of the IEPOX-derived organosulfates were highest during the afternoon and some morning samples in both the "cold" and "hot" periods were consistent with the arrival of oxidized isoprene from the band of oak trees several hours upwind of Blodgett Forest. Concentrations were, on average, a factor of $\sim 10$ higher during the "hot" period in line with larger emissions of isoprene and enhanced photochemistry. These organosulfates are understood to form from heterogeneous uptake of the dihydroxy epoxides of isoprene and have been reported to be prevalent in the free troposphere especially downwind of isoprene sources (Froyd et al., 2010). The mechanism is thought to proceed by acidcatalyzed ring opening of the epoxide group followed by subsequent nucleophilic addition of inorganic sulfate with the presence of highly acidic sulfate seed aerosol being of critical importance to their formation (Surratt et al., 2010). However, as discussed previously the aerosol was not acidic at our site during the study, although acidic plumes might have played a role upwind of the site.

Concentrations of the $\alpha$-pinene-derived nitrooxy organosulfates were highest at night and during some morning samples (Fig. 8), which would be consistent with either mixing down from aloft, from down slope transport of processed air from the previous night or overnight production from $\mathrm{NO}_{3}$ chemistry. There is some evidence for elevated $\mathrm{OA}$ in the absence of 2-propyl nitrate in the early morning (Fig. 2b) that could be indicative of nighttime $\mathrm{NO}_{3}$ chemistry followed by transport to the surface the following day. However, the diurnal variation of OA does not show any substantial nighttime maxima or increases in the early morning that would be consistent with transport to the surface following overnight production aloft. This suggests that either production from $\mathrm{NO}_{3}$ chemistry is not a dominant process or there are more important factors controlling the incorporation of these compounds into the condensed phase. Concentrations were, on average, a factor of $\sim 3$ higher during the "cold" period even though concentrations of the $\alpha$-pinene precursor were lower consistent with other particle phase terpene oxidation products (Fig. 5). The three nitrooxyorganosulfate isomers of $\alpha$ pinene are thought to form from the reactive uptake of the corresponding hydroxynitrates onto acidified sulfate seed aerosols through esterification of the hydroxyl group with sulfuric acid (Surratt et al., 2008). Laboratory chamber studies of the photooxidation $\left(\alpha\right.$-pinene/ $\left.\mathrm{H}_{2} \mathrm{O}_{2} / \mathrm{NO}\right)$ and 


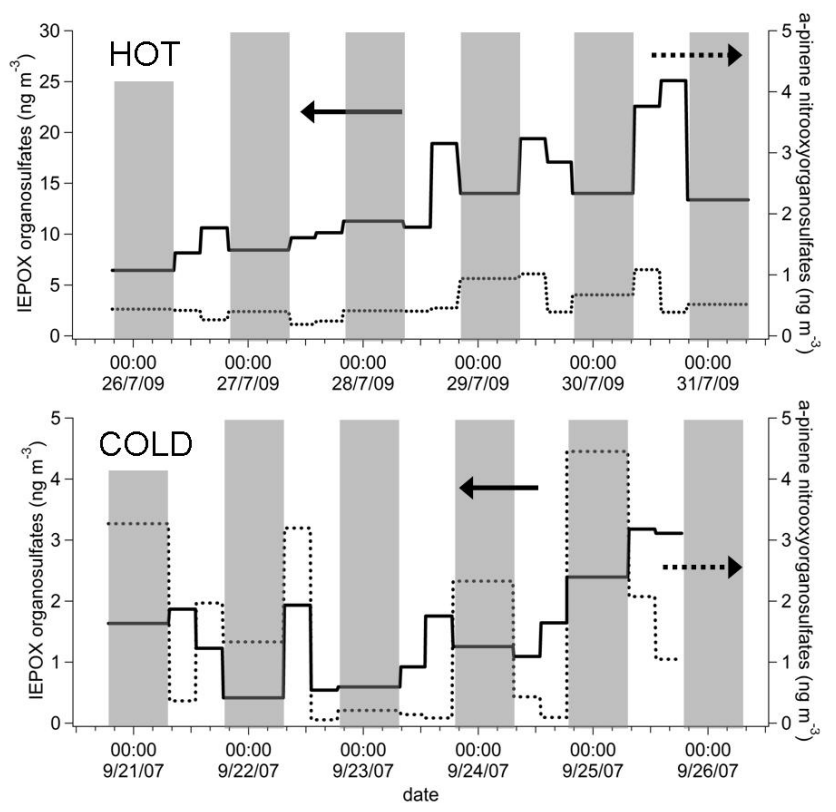

Fig. 8. Time series of the most dominant biogenic organosulfate compounds, IEPOX organosulfates (solid black lines), methacrolein (MACR) organosulfate (dashed black lines) and $\alpha$-pinene nitroxyorganosulfates (dotted gray lines), observed during a 5 day period of high volume filter collections. Shaded bars indicate nighttime.

nighttime oxidation ( $\alpha$-pinene/ $/ \mathrm{NO}_{3} /$ dark) of $\alpha$-pinene in the presence of highly acidic seed aerosol produced three nitrooxyorganosulfates with the same retention times and accurate masses (MW 295) as those reported here (Surratt et al., 2008). The precursor hydroxynitrates can be generated through either $\mathrm{OH}$ initiated photooxidation in the presence of $\mathrm{NO}_{\mathrm{x}}$ or $\mathrm{NO}_{3}$ initiated oxidation (Surratt et al., 2008). It is interesting to note that the intensity of these products was larger in the $\mathrm{NO}_{3}$ experiments and that none of these products were observed in the absence of highly acidified sulfate seed aerosol. Again the need for highly acidic aerosols in the laboratory contrasted with the neutralized aerosol at our site. The exact precursors for these three nitrooxyorganosulfates derived from $\alpha$-pinene remain unclear, and thus, further work is needed to understand their formation and incorporation into ambient aerosols.

\subsection{Varying BSOA contributions to $\mathrm{OA}$ during BEARPEX and possible couplings to $\mathrm{NO}_{x}$ and $\mathrm{SO}_{\mathrm{x}}$ emissions}

Multiple components of BSOA were observed during BEARPEX whose contributions varied as a function of time of day; isoprene oxidation products maximized in the afternoon while many terpene oxidation products were highest at night and other light and temperature derived compounds, such as methyl chavicol and its oxidation product 4-methoxybenzaldehyde, were higher at the beginning and end of the day when light driven emissions could accumulate in a shallow boundary layer. These contributions are also observed to be dependent on meteorological conditions. Contributions of isoprene oxidation products to OA appear to be more substantial during periods of higher temperatures while terpene oxidation products seem to be more important during cooler and wetter conditions and methyl chavicol oxidation seemed to contribute roughly equally to OA during both periods. Higher amounts of monoterpene oxidation products were observed following the first rains of the season and while monoterpene emissions are reportedly sensitive to relative humidity their concentrations were not observed to reach the same levels as during the hot period. Therefore, it appears that the amount of these terpene oxidation products that becomes incorporated into the aerosol phase may be dependent on more factors than simply the emission rate of the precursor compounds. This could suggest differences in the available oxidants or that the precursor monomers (e.g. monoterpene derived organic nitrates) are semi-volatile in nature with a larger percentage partitioning to the condensed phase where oligomerization reactions could occur during cooler nighttime conditions. It is apparent that any increased partitioning of BVOC oxidation products from higher concentrations of biomass burning SOA led to substantially less enhancement of BSOA from terpene oxidation than following the rain events.

There was evidence from the correlation of OA with 2propyl nitrate and $\mathrm{CO}$ along with the ${ }^{14} \mathrm{C}$ data for potential couplings between anthropogenic emissions of $\mathrm{NO}_{\mathrm{x}}$ and BSOA formation. As 2-propyl nitrate is a minor product in the photochemical production of ozone from $\mathrm{NO}_{\mathrm{x}}$ cycling, this correlation suggests a possible coupling between $\mathrm{NO}_{\mathrm{x}}$ and SOA formation that could be related to increased oxidant (i.e. $\mathrm{OH}$ ) formation as implied from work by Carlton et al. (2010). Observations of organosulfates from isoprene and $\alpha$-pinene implied a coupling between these BVOCs, $\mathrm{NO}_{\mathrm{x}}$ and aerosol sulfate. However, concentrations of the quantified organosulfates were small and accounted for $<1 \%$ of the total OA mass and therefore it seems unlikely in this environment that the formation of these compounds was a substantial driving force for the coupling of anthropogenic and biogenic components.

\section{Conclusions}

The organic fraction of the aerosol was dominant $(\sim 75 \%)$ at Blodgett Forest during BEARPEX and, in the absence of sporadic wildfire influence, was on average $\sim 3 \mu \mathrm{g} \mathrm{m}^{-3}$. OA was predominantly "oxygenated" organic aerosol (OOA). Sulfate was the most abundant inorganic component contributing on average $\sim 0.6 \mu \mathrm{g} \mathrm{m}^{-3}(\sim 15 \%)$ to the total observed aerosol loading. OA concentrations peaked at 10$15 \mu \mathrm{g} \mathrm{m}^{-3}$ during wildfire episodes, which were also dominated by OOA, indicating the oxidized and aged state of these 
plumes upon arrival to the site. OA was observed to correlate with anthropogenic tracers (alkyl nitrates and $\mathrm{CO}$ ), consistent with previous studies, and the aerosol carbon was determined to be mostly non-fossil in origin ( $>75 \%)$. This implies that the correlation between OA and an anthropogenic tracer does not necessarily identify the source of the carbon as being anthropogenic and instead implies a coupling between the anthropogenic and biogenic components in the air mass that might be related to the source of the oxidant and/or the aerosol sulfate.

Particle-phase molecular markers were dominated by secondary compounds consistent with the predominance of OOA. A factor analysis of these particle-phase markers along with gas phase compounds identified six factors attributed to the following sources: (1) aged biomass burning emissions and oxidized urban emissions, (2) oxidized urban emissions (3) oxidation products of monoterpene emissions, (4) monoterpene emissions, (5) anthropogenic emissions and (6) local methyl chavicol emissions and oxidation. These were generally consistent with a previous analysis of only gas-phase tracers at the same site (Lamanna and Goldstein, 1999). There was also evidence, from offline filter analysis, for an additional contribution from isoprene oxidation products. Evidence for the likely importance of aerosol sulfate, despite the neutralized nature of the aerosol at our site, was implied from the observations of organosulfates derived from isoprene and $\alpha$-pinene.

Multiple components were observed to contribute to BSOA, which varied both diurnally and seasonally and were not solely dependent on the availability of the precursor compound. Isoprene oxidation products were more important during higher temperatures while terpene oxidation products were more abundant during the cooler and wetter periods. Several high vapor pressure products, including known oxidation products of locally emitted BVOCs (pinonaldehyde and nopinone), were detected in the particle phase as measured by TAG. We speculate that these components were evolved from the particle phase during the thermal desorption cycle and were most likely present as dimers, diols, oligomers or possibly organosulfates when originally collected. These oligomers of terpene oxidation were substantially more abundant during the cold period following the first rains of the fall season in spite of the lower observed concentrations of the precursor compounds. This suggests an unknown mechanism is responsible for the incorporation of these compounds into the particle phase and which may be related to the availability of water in the aerosol phase or possibly due to favorable partitioning of organic nitrates formed from monoterpene oxidation, although there is no definitive evidence for these hypotheses. Further work is needed to understand this process in order to better parameterize BSOA formation in models.

\section{Supplementary material related to this article is available online at: http://www.atmos-chem-phys.net/11/10219/2011/ acp-11-10219-2011-supplement.pdf.}

Acknowledgements. Funding for UCB was provided by the National Science Foundation (NSF, Grant \#0922562) and a University of California Agriculture and Natural Resources (ANR) core issue grant. AHG was partially supported by the Miller Institute in Basic Research in Science at the University of California Berkeley. DKF, KSD and JLJ were supported by NSF ATM-0919189. JBG and JDG were partially supported by the National Science Foundation under grant ATM-0516610. This work was partially performed under the auspices of the U.S. Department of Energy by Lawrence Livermore National Laboratory under Contract DE-AC52-07NA27344. Analyses at the University of Aarhus were partially funded by the NSF US-NORDIC biogenic secondary organic aerosol workshop program. The authors acknowledge Sierra Pacific Industries for the use of their land and the University of California, Berkeley, Center for Forestry, Blodgett Forest Research Station for cooperation in facilitating this research. The authors thank S. S. Cliff (University of California, Davis) for the loan of the high volume filter sampler. N. C. Bouvier-Brown (Loyola Marymount University, Los Angeles), Y. Zhao and E. C. Browne (University of California, Berkeley) for their help with filter collection. N. C. Bouvier-Brown is also thanked for providing the gas phase methyl chavicol data used in the factor analysis and D. M. Matross (University of California, Berkeley) for making the PTR-MS gradient measurements used to normalize the gas phase methyl chavicol data used in the factor analysis. A. Frossard (University of California, San Diego) for assistance with TAG and Brian LaFranchi (Lawrence Livermore National Laboratory) for writing the data merging code. We are grateful to Nathan Eddingsaas (Caltech) for providing the BEPOX-derived organosulfate standard and Yoshiteru Iinuma (Leibniz-Institut fuer Troposphaerenforschung) for providing the $\beta$-pinene oxide derived organosulfate standard used for quantification of IEPOX- and $\beta$-pinene-derived organosulfates, respectively, by LC/ESI-MS techniques. Additionally, we would also like to thank Man Nin Chan and Katherine Schilling (Caltech) for their assistance with filter extractions and UPLC/ESI-HR-TOFMS analyses.

Edited by: N. M. Donahue

\section{References}

Aiken, A. C., DeCarlo, P. F., Kroll, J. H., Worsnop, D. R., Huffman, J. A., Docherty, K. S., Ulbrich, I. M., Mohr, C., Kimmel, J. R., Sueper, D., Sun, Y., Zhang, Q., Trimborn, A., Northway, M., Ziemann, P. J., Canagaratna, M. R., Onasch, T. B., Alfarra, M. R., Prevot, A. S. H., Dommen, J., Duplissy, J., Metzger, A., Baltensperger, U., and Jimenez, J. L.: O/C and OM/OC ratios of primary, secondary, and ambient organic aerosols with high-resolution time-of-flight aerosol mass spectrometry, Environ. Sci. Technol., 42, 4478-485, doi:10.1021/es703009q, 2008.

Aiken, A. C., de Foy, B., Wiedinmyer, C., DeCarlo, P. F., U1brich, I. M., Wehrli, M. N., Szidat, S., Prevot, A. S. H., Noda, J., Wacker, L., Volkamer, R., Fortner, E., Wang, J., Laskin, A., 
Shutthanandan, V., Zheng, J., Zhang, R., Paredes-Miranda, G., Arnott, W. P., Molina, L. T., Sosa, G., Querol, X., and Jimenez, J. L.: Mexico city aerosol analysis during MILAGRO using high resolution aerosol mass spectrometry at the urban supersite (T0) - Part 2: Analysis of the biomass burning contribution and the non-fossil carbon fraction, Atmos. Chem. Phys., 10, 5315-5341, doi:10.5194/acp-10-5315-2010, 2010.

Allan, J. D., Delia, A. E., Coe, H., Bower, K. N., Alfarra, M. R., Jimenez, J. L., Middlebrook, A. M., Drewnick, F., Onasch, T. B., Canagaratna, M. R., Jayne, J. T., and Worsnop, D. R.: A generalised method for the extraction of chemically resolved mass spectra from aerodyne aerosol mass spectrometer data, J. Aerosol Sci., 35, 909-922, doi:10.1016/j.jaerosci.2004.02.007, 2004.

Alves, C. A., Pio, C. A., and Duarte, A. C.: Particulate size distributed organic: Compounds in a forest atmosphere, Environ. Sci. Technol., 34, 4287-4293, doi:10.1021/es000028a, 2000.

Andreae, M. O. and Merlet, P.: Emission of trace gases and aerosols from biomass burning, Global Biogeochem. Cy., 15, 955-966, 2001.

Atkinson, R. and Arey, J.: Atmospheric degradation of volatile organic compounds, Chem. Rev., 103, 4605-4638, 2003.

Atkinson, R., Baulch, D. L., Cox, R. A., Crowley, J. N., Hampson, R. F., Hynes, R. G., Jenkin, M. E., Rossi, M. J., Troe, J., and IUPAC Subcommittee: Evaluated kinetic and photochemical data for atmospheric chemistry: Volume II - gas phase reactions of organic species, Atmos. Chem. Phys., 6, 3625-4055, doi:10.5194/acp-6-3625-2006, 2006.

Bahreini, R., Ervens, B., Middlebrook, A. M., Warneke, C., de Gouw, J. A., DeCarlo, P. F., Jimenez, J. L., Brock, C. A., Neuman, J. A., Ryerson, T. B., Stark, H., Atlas, E., Brioude, J., Fried, A., Holloway, J. S., Peischl, J., Richter, D., Walega, J., Weibring, P., Wollny, A. G., and Fehsenfeld, F. C.: Organic aerosol formation in urban and industrial plumes near Houston and Dallas, Texas, J. Geophys. Res.-Atmos., 114, D00F16, doi:10.1029/2008jd011493, 2009.

Bench, G. and Herckes, P.: Measurement of contemporary and fossil carbon contents of PM2.5 aerosols: Results from Turtleback Dome, Yosemite National Park, Environ. Sci. Technol., 38, 2424-2427, doi:10.1021/es035161s, 2004.

Bench, G., Fallon, S., Schichtel, B., Malm, W., and McDade, C.: Relative contributions of fossil and contemporary carbon sources to $\mathrm{PM}_{2.5}$ aerosols at nine Interagency Monitoring for Protection of Visual Environments (IMPROVE) network sites, J. Geophys. Res.-Atmos., 112, D10205, doi:10.1029/2006jd007708, 2007.

Bouvier-Brown, N. C., Holzinger, R., Palitzsch, K., and Goldstein, A. H.: Quantifying sesquiterpene and oxygenated terpene emissions from live vegetation using solid-phase microextraction fibers, J. Chromatogr. A, 1161, 113-120, 2007.

Bouvier-Brown, N. C., Goldstein, A. H., Gilman, J. B., Kuster, W. C., and de Gouw, J. A.: In-situ ambient quantification of monoterpenes, sesquiterpenes, and related oxygenated compounds during BEARPEX 2007: implications for gas- and particle-phase chemistry, Atmos. Chem. Phys., 9, 5505-5518, doi:10.5194/acp-9-5505-2009, 2009a.

Bouvier-Brown, N. C., Goldstein, A. H., Worton, D. R., Matross, D. M., Gilman, J. B., Kuster, W. C., Welsh-Bon, D., Warneke, C., de Gouw, J. A., Cahill, T. M., and Holzinger, R.: Methyl chavicol: characterization of its biogenic emission rate, abundance, and oxidation products in the atmosphere, Atmos. Chem. Phys.,
9, 2061-2074, doi:10.5194/acp-9-2061-2009, 2009b.

Brown, S. S., deGouw, J. A., Warneke, C., Ryerson, T. B., Dubé, W. P., Atlas, E., Weber, R. J., Peltier, R. E., Neuman, J. A., Roberts, J. M., Swanson, A., Flocke, F., McKeen, S. A., Brioude, J., Sommariva, R., Trainer, M., Fehsenfeld, F. C., and Ravishankara, A. R.: Nocturnal isoprene oxidation over the Northeast United States in summer and its impact on reactive nitrogen partitioning and secondary organic aerosol, Atmos. Chem. Phys., 9, 30273042, doi:10.5194/acp-9-3027-2009, 2009.

Cahill, T. M., Seaman, V. Y., Charles, M. J., Holzinger, R., and Goldstein, A. H.: Secondary organic aerosols formed from oxidation of biogenic volatile organic compounds in the Sierra Nevada Mountains of California, J. Geophys. Res.-Atmos., 111, D16312, doi:10.1029/2006JD007178, 2006.

Carlton, A. G., Pinder, R. W., Bhave, P. V., and Pouliot, G. A.: To What Extent Can Biogenic SOA be Controlled?, Environ. Sci. Technol., 44, 3376-3380, doi:10.1021/es903506b, 2010.

Chan, A. W. H., Chan, M. N., Surratt, J. D., Chhabra, P. S., Loza, C. L., Crounse, J. D., Yee, L. D., Flagan, R. C., Wennberg, P. O., and Seinfeld, J. H.: Role of aldehyde chemistry and $\mathrm{NO}_{\mathrm{x}}$ concentrations in secondary organic aerosol formation, Atmos. Chem. Phys., 10, 7169-7188, doi:10.5194/acp-10-7169-2010, 2010.

Chan, M. N., Surratt, J. D., Chan, A. W. H., Schilling, K., Offenberg, J. H., Lewandowski, M., Edney, E. O., Kleindienst, T. E., Jaoui, M., Edgerton, E. S., Tanner, R. L., Shaw, S. L., Zheng, M., Knipping, E. M., and Seinfeld, J. H.: Influence of aerosol acidity on the chemical composition of secondary organic aerosol from $\beta$-caryophyllene, Atmos. Chem. Phys., 11, 1735-1751, doi:10.5194/acp-11-1735-2011, 2011.

Chen, Q., Farmer, D. K., Schneider, J., Zorn, S. R., Heald, C. L., Karl, T. G., Guenther, A., Allan, J. D., Robinson, N., Coe, H., Kimmel, J. R., Pauliquevis, T., Borrmann, S., Pöschl, U., Andreae, M. O., Artaxo, P., Jimenez, J. L., and Martin, S. T.: Mass spectral characterization of submicron biogenic organic particles in the Amazon Basin, Geophys. Res. Lett., 36, L20806, doi:10.1029/2009g1039880, 2009.

Cubison, M. J., Ortega, A. M., Hayes, P. L., Farmer, D. K., Day, D., Lechner, M. J., Brune, W. H., Apel, E., Diskin, G. S., Fisher, J. A., Fuelberg, H. E., Hecobian, A., Knapp, D. J., Mikoviny, T., Riemer, D., Sachse, G. W., Sessions, W., Weber, R. J., Weinheimer, A. J., Wisthaler, A., and Jimenez, J. L.: Effects of aging on organic aerosol from open biomass burning smoke in aircraft and lab studies, Atmos. Chem. Phys. Discuss., 11, 12103-12140, doi:10.5194/acpd-11-12103-2011, 2011.

Day, D. A., Farmer, D. K., Goldstein, A. H., Wooldridge, P. J., Minejima, C., and Cohen, R. C.: Observations of $\mathrm{NO}_{\mathrm{x}}, \Sigma \mathrm{PNs}$, $\Sigma$ ANs, and $\mathrm{HNO}_{3}$ at a Rural Site in the California Sierra Nevada Mountains: summertime diurnal cycles, Atmos. Chem. Phys., 9, 4879-4896, doi:10.5194/acp-9-4879-2009, 2009.

de Gouw, J. and Warneke, C.: Measurements of volatile organic compounds in the earths atmosphere using proton-transferreaction mass spectrometry, Mass Spectrom. Rev., 26, 223-257, doi:10.1002/mas.20119, 2007.

de Gouw, J. A., Middlebrook, A. M., Warneke, C., Goldan, P. D., Kuster, W. C., Roberts, J. M., Fehsenfeld, F. C., Worsnop, D. R., Canagaratna, M. R., Pszenny, A. A. P., Keene, W. C., Marchewka, M., Bertman, S. B., and Bates, T. S.: Budget of organic carbon in a polluted atmosphere: Results from the New England Air Quality Study in 2002, J. Geophys. Res.-Atmos., 
110, D16305, doi:10.1029/2004jd005623, 2005.

de Gouw, J. A., Middlebrook, A. M., Warneke, C., Ahmadov, R., Atlas, E. L., Bahreini, R., Blake, D. R., Brock, C. A., Brioude, J., Fahey, D. W., Fehsenfeld, F. C., Holloway, J. S., Le Henaff, M., Lueb, R. A., McKeen, S. A., Meagher, J. F., Murphy, D. M., Paris, C., Parrish, D. D., Perring, A. E., Pollack, I. B., Ravishankara, A. R., Robinson, A. L., Ryerson, T. B., Schwarz, J. P., Spackman, J. R., Srinivasan, A., and Watts, L. A.: Organic aerosol formation downwind from the Deepwater Horizon oil spill, Science, 331, 1295-1299, 2011.

DeCarlo, P. F., Kimmel, J. R., Trimborn, A., Northway, M. J., Jayne, J. T., Aiken, A. C., Gonin, M., Fuhrer, K., Horvath, T., Docherty, K. S., Worsnop, D. R., and Jimenez, J. L.: Field-deployable, high-resolution, time-of-flight aerosol mass spectrometer, Anal. Chem., 78, 8281-8289, doi:10.1021/ac061249n, 2006.

DeCarlo, P. F., Ulbrich, I. M., Crounse, J., de Foy, B., Dunlea, E. J., Aiken, A. C., Knapp, D., Weinheimer, A. J., Campos, T., Wennberg, P. O., and Jimenez, J. L.: Investigation of the sources and processing of organic aerosol over the Central Mexican Plateau from aircraft measurements during MILAGRO, Atmos. Chem. Phys., 10, 5257-5280, doi:10.5194/acp-10-52572010, 2010.

Dillon, M. B., Lamanna, M. S., Schade, G. W., Goldstein, A. H., and Cohen, R. C.: Chemical evolution of the Sacramento urban plume: Transport and oxidation, J. Geophys. Res.-Atmos., 107, 4045, doi:10.1029/2001jd000969, 2002.

Dreyfus, G. B., Schade, G. W., and Goldstein, A. H.: Observational constraints on the contribution of isoprene oxidation to ozone production on the western slope of the Sierra Nevada, California, J. Geophys. Res.-Atmos., 107, 4365, doi:10.1029/2001jd001490, 2002.

Dzepina, K., Volkamer, R. M., Madronich, S., Tulet, P., Ulbrich, I. M., Zhang, Q., Cappa, C. D., Ziemann, P. J., and Jimenez, J. L.: Evaluation of recently-proposed secondary organic aerosol models for a case study in Mexico City, Atmos. Chem. Phys., 9, 5681-5709, doi:10.5194/acp-9-5681-2009, 2009.

Ervens, B., Carlton, A. G., Turpin, B. J., Altieri, K. E., Kreidenweis, S. M., and Feingold, G.: Secondary organic aerosol yields from cloud-processing of isoprene oxidation products, Geophys. Res. Lett., 35, L02816, doi:10.1029/2007gl031828, 2008.

Farmer, D. K., Matsunaga, A., Docherty, K. S., Surratt, J. D., Seinfeld, J. H., Ziemann, P. J., and Jimenez, J. L.: Response of an aerosol mass spectrometer to organonitrates and organosulfates and implications for atmospheric chemistry, P. Natl. Acad. Sci. USA, 107, 6670-6675, doi:10.1073/pnas.0912340107, 2010.

Farmer, D. K., Kimmel, J. R., Phillips, G., Docherty, K. S., Worsnop, D. R., Sueper, D., Nemitz, E., and Jimenez, J. L.: Eddy covariance measurements with high-resolution time-offlight aerosol mass spectrometry: a new approach to chemically resolved aerosol fluxes, Atmos. Meas. Tech., 4, 1275-1289, doi:10.5194/amt-4-1275-2011, 2011.

Fine, P. M., Chakrabarti, B., Krudysz, M., Schauer, J. J., and Sioutas, C.: Diurnal variations of individual organic compound constituents of ultrafine and accumulation mode particulate matter in the Los Angeles basin, Environ. Sci. Technol., 38, 12961304, doi:10.1021/es0348389, 2004.

Forstner, H. J. L., Flagan, R. C., and Seinfeld, J. H.: Molecular speciation of secondary organic aerosol from photooxidation of the higher alkenes: 1-octene and 1-decene, Atmos. Environ., 31,
1953-1964, 1997a.

Forstner, H. J. L., Flagan, R. C., and Seinfeld, J. H.: Secondary organic aerosol from the photooxidation of aromatic hydrocarbons: Molecular composition, Environ. Sci. Technol., 31, 1345-1358, $1997 b$.

Froyd, K. D., Murphy, S. M., Murphy, D. M., de Gouw, J. A., Eddingsaas, N. C., and Wennberg, P. O.: Contribution of isoprene-derived organosulfates to free tropospheric aerosol mass, P. Natl. Acad. Sci. USA, 107, 21360-21365, doi:10.1073/pnas.1012561107, 2010.

Gao, S., Ng, N. L., Keywood, M., Varutbangkul, V., Bahreini, R., Nenes, A., He, J. W., Yoo, K. Y., Beauchamp, J. L., Hodyss, R. P., Flagan, R. C., and Seinfeld, J. H.: Particle phase acidity and oligomer formation in secondary organic aerosol, Environ. Sci. Technol., 38, 6582-6589, doi:10.1021/es049125k, 2004.

Gentner, D. R., Harley, R. A., Miller, A. M., and Goldstein, A. H.: Diurnal and seasonal variability of gasoline related volatile organic compound emissions in Riverside, California, Environ. Sci. Technol., 43, 4247-4252, 2009.

Gilman, J. B., Burkhart, J. F., Lerner, B. M., Williams, E. J., Kuster, W. C., Goldan, P. D., Murphy, P. C., Warneke, C., Fowler, C., Montzka, S. A., Miller, B. R., Miller, L., Oltmans, S. J., Ryerson, T. B., Cooper, O. R., Stohl, A., and de Gouw, J. A.: Ozone variability and halogen oxidation within the Arctic and sub-Arctic springtime boundary layer, Atmos. Chem. Phys., 10, 10223-10236, doi:10.5194/acp-10-10223-2010, 2010.

Goldstein, A. H., Hultman, N. E., Fracheboud, J. M., Bauer, M. R., Panek, J. A., Xu, M., Qi, Y., Guenther, A. B., and Baugh, W.: Effects of climate variability on the carbon dioxide, water, and sensible heat fluxes above a ponderosa pine plantation in the Sierra Nevada (CA), Agric. Forest Meteorol., 101, 113-129, 2000.

Goldstein, A. H., McKay, M., Kurpius, M. R., Schade, G. W., Lee, A., Holzinger, R., and Rasmussen, R. A.: Forest thinning experiment confirms ozone deposition to forest canopy is dominated by reaction with biogenic VOCs, Geophys. Res. Lett., 31, L22106, doi:10.1029/2004g1021259, 2004.

Goldstein, A. H. and Galbally, I. E.: Known and unexplored organic constituents in the earth's atmosphere, Environ. Sci. Technol., 41, 1514-1521, 2007.

Goldstein, A. H., Koven, C. D., Heald, C. L., and Fung, I. Y.: Biogenic carbon and anthropogenic pollutants combine to form a cooling haze over the southeastern United States, P. Natl. Acad. Sci. USA, 106, 8835-8840, doi:10.1073/pnas.0904128106, 2009.

Grieshop, A. P., Logue, J. M., Donahue, N. M., and Robinson, A. L.: Laboratory investigation of photochemical oxidation of organic aerosol from wood fires 1: measurement and simulation of organic aerosol evolution, Atmos. Chem. Phys., 9, 1263-1277, doi:10.5194/acp-9-1263-2009, 2009.

Griffin, R. J., Chen, J. J., Carmody, K., Vutukuru, S., and Dabdub, D.: Contribution of gas phase oxidation of volatile organic compounds to atmospheric carbon monoxide levels in two areas of the United States, J. Geophys. Res., 112, D10S17, doi:10.1029/2006jd007602, 2007.

Guenther, A., Hewitt, C. N., Erickson, D., Fall, R., Geron, C., Graedel, T., Harley, P., Klinger, L., Lerdau, M., McKay, W. A., Pierce, T., Scholes, B., Steinbrecher, R., Tallamraju, R., Taylor, J., and Zimmerman, P.: A global model of natural volatile organic compound emissions, J. Geophys. Res.-Atmos., 100, 
8873-8892, 1995.

Guenther, A. B., Zimmerman, P. R., Harley, P. C., Monson, R. K., and Fall, R.: Isoprene and monoterpene emission rate variability - Model evaluations and sensitivity analyses, J. Geophys. Res.Atmos., 98, 12609-12617, 1993.

Hall, W. A. and Johnston, M. V.: Oligomer Content of alphaPinene Secondary Organic Aerosol, Aerosol Sci. Tech., 45, 3745, doi:10.1080/02786826.2010.517580, 2011.

Hallquist, M., Wangberg, I., and Ljungstrom, E.: Atmospheric fate of carbonyl oxidation products originating from alpha-pinene and Delta(3)-carene: Determination of rate of reaction with $\mathrm{OH}$ and $\mathrm{NO}_{3}$ radicals, UV absorption cross sections, and vapor pressures, Environ. Sci. Technol., 31, 3166-3172, 1997.

Heald, C. L., Jacob, D. J., Park, R. J., Russell, L. M., Huebert, B. J., Seinfeld, J. H., Liao, H., and Weber, R. J.: A large organic aerosol source in the free troposphere missing from current models, Geophys. Res. Lett., 32, L18809, doi:10.1029/2005g1023831, 2005.

Heald, C. L., Ridley, D. A., Kreidenweis, S. M., and Drury, E. E.: Satellite observations cap the atmospheric organic aerosol budget, Geophys. Res. Lett., 37, L24808, doi:10.1029/2010g1045095, 2010.

Hildemann, L. M., Klinedinst, D. B., Klouda, G. A., Currie, L. A., and Cass, G. R.: Sources of urban contemporary carbon aerosol, Environ. Sci. Technol., 28, 1565-1576, 1994.

Hodzic, A., Jimenez, J. L., Madronich, S., Canagaratna, M. R., DeCarlo, P. F., Kleinman, L., and Fast, J.: Modeling organic aerosols in a megacity: potential contribution of semi-volatile and intermediate volatility primary organic compounds to secondary organic aerosol formation, Atmos. Chem. Phys., 10, 5491-5514, doi:10.5194/acp-10-5491-2010, 2010a.

Hodzic, A., Jimenez, J. L., Prévôt, A. S. H., Szidat, S., Fast, J. D., and Madronich, S.: Can 3-D models explain the observed fractions of fossil and non-fossil carbon in and near Mexico City?, Atmos. Chem. Phys., 10, 10997-11016, doi:10.5194/acp10-10997-2010, 2010b.

Holzinger, R., Lee, A., Paw, K. T., and Goldstein, U. A. H.: Observations of oxidation products above a forest imply biogenic emissions of very reactive compounds, Atmos. Chem. Phys., 5, 67-75, doi:10.5194/acp-5-67-2005, 2005.

Hoyle, C. R., Boy, M., Donahue, N. M., Fry, J. L., Glasius, M., Guenther, A., Hallar, A. G., Huff Hartz, K., Petters, M. D., Petäjä, T., Rosenoern, T., and Sullivan, A. P.: A review of the anthropogenic influence on biogenic secondary organic aerosol, Atmos. Chem. Phys., 11, 321-343, doi:10.5194/acp-11-321-2011, 2011.

Hudman, R. C., Murray, L. T., Jacob, D. J., Millet, D. B., Turquety, S., Wu, S., Blake, D. R., Goldstein, A. H., Holloway, J., and Sachse, G. W.: Biogenic versus anthropogenic sources of CO in the United States, Geophys. Res. Lett., 35, L04801, doi:10.1029/2007g1032393, 2008.

Jang, M. S., Czoschke, N. M., Lee, S., and Kamens, R. M.: Heterogeneous atmospheric aerosol production by acid-catalyzed particle-phase reactions, Science, 298, 814-817, 2002.

Jayne, J. T., Leard, D. C., Zhang, X. F., Davidovits, P., Smith, K. A., Kolb, C. E., and Worsnop, D. R.: Development of an aerosol mass spectrometer for size and composition analysis of submicron particles, Aerosol Sci. Tech., 33, 49-70, 2000.

Jenkins, B. M., Jones, A. D., Turn, S. Q., and Williams, R. B.: Emis- sion factors for polycyclic aromatic hydrocarbons from biomass burning, Environ. Sci. Technol., 30, 2462-2469, 1996.

Jimenez, J. L., Jayne, J. T., Shi, Q., Kolb, C. E., Worsnop, D. R., Yourshaw, I., Seinfeld, J. H., Flagan, R. C., Zhang, X. F., Smith, K. A., Morris, J. W., and Davidovits, P.: Ambient aerosol sampling using the Aerodyne Aerosol Mass Spectrometer, J. Geophys. Res.-Atmos., 108, 8425, doi:10.1029/2001jd001213, 2003. Jimenez, J. L., Canagaratna, M. R., Donahue, N. M., Prevot, A. S. H., Zhang, Q., Kroll, J. H., DeCarlo, P. F., Allan, J. D., Coe, H., Ng, N. L., Aiken, A. C., Docherty, K. S., Ulbrich, I. M., Grieshop, A. P., Robinson, A. L., Duplissy, J., Smith, J. D., Wilson, K. R., Lanz, V. A., Hueglin, C., Sun, Y. L., Tian, J., Laaksonen, A., Raatikainen, T., Rautiainen, J., Vaattovaara, P., Ehn, M., Kulmala, M., Tomlinson, J. M., Collins, D. R., Cubison, M. J., Dunlea, E. J., Huffman, J. A., Onasch, T. B., Alfarra, M. R., Williams, P. I., Bower, K., Kondo, Y., Schneider, J., Drewnick, F., Borrmann, S., Weimer, S., Demerjian, K., Salcedo, D., Cottrell, L., Griffin, R., Takami, A., Miyoshi, T., Hatakeyama, S., Shimono, A., Sun, J. Y., Zhang, Y. M., Dzepina, K., Kimmel, J. R., Sueper, D., Jayne, J. T., Herndon, S. C., Trimborn, A. M., Williams, L. R., Wood, E. C., Middlebrook, A. M., Kolb, C. E., Baltensperger, U., and Worsnop, D. R.: Evolution of Organic Aerosols in the Atmosphere, Science, 326, 1525-1529, doi:10.1126/science.1180353, 2009.

Kanakidou, M., Seinfeld, J. H., Pandis, S. N., Barnes, I., Dentener, F. J., Facchini, M. C., Van Dingenen, R., Ervens, B., Nenes, A., Nielsen, C. J., Swietlicki, E., Putaud, J. P., Balkanski, Y., Fuzzi, S., Horth, J., Moortgat, G. K., Winterhalter, R., Myhre, C. E. L., Tsigaridis, K., Vignati, E., Stephanou, E. G., and Wilson, J.: Organic aerosol and global climate modelling: a review, Atmos. Chem. Phys., 5, 1053-1123, doi:10.5194/acp-5-1053-2005, 2005.

Kautzman, K. E., Surratt, J. D., Chan, M. N., Chan, A. W. H., Hersey, S. P., Chhabra, P. S., Dalleska, N. F., Wennberg, P. O., Flagan, R. C., and Seinfeld, J. H.: Chemical composition of gas and aerosol phase products from the photooxidation of naphthalene, J. Phys. Chem. A, 114, 913-934, doi:10.1021/jp908530s, 2010.

Kebarle, P.: A brief overview of the present status of the mechanisms involved in electrospray mass spectrometry, J. Mass Spectrom., 35, 804-817, 2000.

Kleindienst, T. E., Lewandowski, M., Offenberg, J. H., Edney, E. O., Jaoui, M., Zheng, M., Ding, X. A., and Edgerton, E. S.: Contribution of Primary and Secondary Sources to Organic Aerosol and PM2.5 at SEARCH Network Sites, J. Air Waste Manage., 60, 1388-1399, doi:10.3155/1047-3289.60.11.1388, 2010.

Kreisberg, N. M., Hering, S. V., Williams, B. J., Worton, D. R., and Goldstein, A. H.: Quantification of Hourly Speciated Organic Compounds in Atmospheric Aerosols, measured by an In-Situ Thermal Desorption Aerosol Gas Chromatograph (TAG), Aerosol Sci. Technol., 43, 38-52, doi:10.1080/02786820802459583, 2009.

Kristensen, K. and Glasius, M.: Organosulfates and oxidation products from biogenic hydrocarbons in fine aerosols from a forest in North West Europe during spring, Atmos. Environ., 45, 45464556, 2011.

Kroll, J. H., Ng, N. L., Murphy, S. M., Varutbangkul, V., Flagan, R. C., and Seinfeld, J. H.: Chamber studies of secondary organic aerosol growth by reactive uptake of simple 
carbonyl compounds, J. Geophys. Res.-Atmos., 110, D23207, doi:10.1029/2005jd006004, 2005.

Kurpius, M. R. and Goldstein, A. H.: Gas-phase chemistry dominates $\mathrm{O}_{3}$ loss to a forest, implying a source of aerosols and hydroxyl radicals to the atmosphere, Geophys. Res. Lett., 30, 1371, doi:10.1029/2002g1016785, 2003.

LaFranchi, B. W., Goldstein, A. H., and Cohen, R. C.: Observations of the temperature dependent response of ozone to $\mathrm{NO}_{\mathrm{x}}$ reductions in the Sacramento, CA urban plume, Atmos. Chem. Phys., 11, 6945-6960, doi:10.5194/acp-11-6945-2011, 2011.

Lamanna, M. S. and Goldstein, A. H.: In situ measurements of C2-C-10 volatile organic compounds above a Sierra Nevada ponderosa pine plantation, J. Geophys. Res.-Atmos., 104, $21247-$ 21262, 1999.

Lee, A., Goldstein, A. H., Kroll, J. H., Ng, N. L., Varutbangkul, V., Flagan, R. C., and Seinfeld, J. H.: Gas-phase products and secondary aerosol yields from the photooxidation of 16 different terpenes, J. Geophys. Res.-Atmos., 111, D17305, doi:10.1029/2006jd007050, 2006.

Levin, I., Naegler, T., Kromer, B., Diehl, M., Francey, R. J., GomezPelaez, A. J., Steele, L. P., Wagenbach, D., Weller, R., and Worthy, D. E.: Observations and modelling of the global distribution and long-term trend of atmospheric $14 \mathrm{CO}(2)$, Tellus B, 62, 2646, doi:10.1111/j.1600-0889.2009.00446.x, 2010.

Lin, Y. C., Cho, J., Tompsett, G. A., Westmoreland, P. R., and Huber, G. W.: Kinetics and Mechanism of Cellulose Pyrolysis, J. Phys. Chem. C, 113, 20097-20107, doi:10.1021/jp906702p, 2009.

Lunden, M. M., Black, D. R., McKay, M., Revzan, K. L., Goldstein, A. H., and Brown, N. J.: Characteristics of fine particle growth events observed above a forested ecosystem in the Sierra Nevada Mountains of California, Aerosol Sci. Tech., 40, 373388, doi:10.1080/02786820600631896, 2006.

Ma, Y. L. and Hays, M. D.: Thermal extraction-two-dimensional gas chromatography-mass spectrometry with heart-cutting for nitrogen heterocyclics in biomass burning aerosols, J. Chromatogr. A, 1200, 228-234, doi:10.1016/j.chroma.2008.05.078, 2008.

Middleton, P.: Chapter 4: Sources of air pollutants, in: Composition, chemistry and climate of the atmosphere, edited by: Singh, H. B., Van Nostramd Reinhold, New York, 88-119, 1995.

Müller, L., Reinnig, M.-C., Warnke, J., and Hoffmann, Th.: Unambiguous identification of esters as oligomers in secondary organic aerosol formed from cyclohexene and cyclohexene $/ \alpha$ pinene ozonolysis, Atmos. Chem. Phys., 8, 1423-1433, doi:10.5194/acp-8-1423-2008, 2008.

Murphy, J. G., Day, A., Cleary, P. A., Wooldridge, P. J., and Cohen, R. C.: Observations of the diurnal and seasonal trends in nitrogen oxides in the western Sierra Nevada, Atmos. Chem. Phys., 6, 5321-5338, 2006,

http://www.atmos-chem-phys.net/6/5321/2006/.

Murphy, J. G., Day, D. A., Cleary, P. A., Wooldridge, P. J., Millet, D. B., Goldstein, A. H., and Cohen, R. C.: The weekend effect within and downwind of Sacramento -Part 1: Observations of ozone, nitrogen oxides, and VOC reactivity, Atmos. Chem. Phys., 7, 5327-5339, doi:10.5194/acp-7-5327-2007, 2007.

Ng, N. L., Kroll, J. H., Chan, A. W. H., Chhabra, P. S., Flagan, R. C., and Seinfeld, J. H.: Secondary organic aerosol formation from m-xylene, toluene, and benzene, Atmos. Chem. Phys., 7, 3909-3922, doi:10.5194/acp-7-3909-2007, 2007.
Odum, J. R., Hoffmann, T., Bowman, F., Collins, D., Flagan, R. C., and Seinfeld, J. H.: Gas/particle partitioning and secondary organic aerosol yields, Environ. Sci. Technol., 30, 2580-2585, 1996.

Offenberg, J. H., Lewandowski, M., Jaoui, M., and Kleindienst, T. E.: Contributions of biogenic and anthropogenic hydrocarbons to secondary organic aerosol during 2006 in research Triangle Park, NC, Aerosol Air Qual. Res., 11, 99-108, 2011.

Paulot, F., Crounse, J. D., Kjaergaard, H. G., Kurten, A., St. Clair, J. M., Seinfeld, J. H., and Wennberg, P. O.: Unexpected Epoxide Formation in the Gas-Phase Photooxidation of Isoprene, Science, 325, 730-733, doi:10.1126/science.1172910, 2009.

Peltier, R. E., Sullivan, A. P., Weber, R. J., Wollny, A. G., Holloway, J. S., Brock, C. A., de Gouw, J. A., and Atlas, E. L.: No evidence for acid-catalyzed secondary organic aerosol formation in power plant plumes over metropolitan Atlanta, Georgia, Geophys. Res. Lett., 34, L06801, doi:10.1029/2006g1028780, 2007.

Pierotti, D., Wofsy, S. C., Jacob, D., and Rasmussen, R. A.: Isoprene and its oxidation products - methacrolein and methyl vinyl ketone, J. Geophys. Res.-Atmos., 95, 1871-1881, 1990.

Pye, H. O. T. and Seinfeld, J. H.: A global perspective on aerosol from low-volatility organic compounds, Atmos. Chem. Phys., 10, 4377-4401, doi:10.5194/acp-10-4377-2010, 2010.

Rhead, M. M. and Pemberton, R. D.: Sources of naphthalene in diesel exhaust emissions, Energy Fuels, 10, 837-843, 1996.

Robinson, A. L., Donahue, N. M., Shrivastava, M. K., Weitkamp, E. A., Sage, A. M., Grieshop, A. P., Lane, T. E., Pierce, J. R., and Pandis, S. N.: Rethinking organic aerosols: Semivolatile emissions and photochemical aging, Science, 315, 1259-1262, doi:10.1126/science.1133061, 2007.

Rogge, W. F., Hildemann, L. M., Mazurek, M. A., Cass, G. R., and Simoneit, B. R. T.: Mathematical modeling of atmospheric fine particle-associated primary organic compound concentrations, J. Geophys. Res.-Atmos., 101, 19379-19394, 1996.

Schade, G. W. and Goldstein, A. H.: Fluxes of oxygenated volatile organic compounds from a ponderosa pine plantation, J. Geophys. Res.-Atmos., 106, 3111-3123, 2001.

Schade, G. W., Goldstein, A. H., and Lamanna, M. S.: Are monoterpene emissions influenced by humidity?, Geophys. Res. Lett., 26, 2187-2190, 1999.

Schauer, J. J., Rogge, W. F., Hildemann, L. M., Mazurek, M. A., and Cass, G. R.: Source apportionment of airborne particulate matter using organic compounds as tracers, Atmos. Environ., 30, 3837-3855, 1996.

Schichtel, B. A., Malm, W. C., Bench, G., Fallon, S., McDade, C. E., Chow, J. C., and Watson, J. G.: Fossil and contemporary fine particulate carbon fractions at 12 rural and urban sites in the United States, J. Geophys. Res.-Atmos., 113, D02311, doi:10.1029/2007jd008605, 2008.

Seinfeld, J. H. and Pankow, J. F.: Organic atmospheric particulate material, Annu. Rev. Phys. Chem., 54, 121-140, doi:10.1146/annurev.physchem.54.011002.103756, 2003.

Simoneit, B. R. T., Schauer, J. J., Nolte, C. G., Oros, D. R., Elias, V. O., Fraser, M. P., Rogge, W. F., and Cass, G. R.: Levoglucosan, a tracer for cellulose in biomass burning and atmospheric particles, Atmos. Environ., 33, 173-182, 1999.

Slowik, J. G., Stroud, C., Bottenheim, J. W., Brickell, P. C., Chang, R. Y.-W., Liggio, J., Makar, P. A., Martin, R. V., Moran, M. D., Shantz, N. C., Sjostedt, S. J., van Donkelaar, A., Vlasenko, A., 
Wiebe, H. A., Xia, A. G., Zhang, J., Leaitch, W. R., and Abbatt, J. P. D.: Characterization of a large biogenic secondary organic aerosol event from eastern Canadian forests, Atmos. Chem. Phys., 10, 2825-2845, doi:10.5194/acp-10-2825-2010, 2010.

Spracklen, D. V., Jimenez, J. L., Carslaw, K. S., Worsnop, D. R., Evans, M. J., Mann, G. W., Zhang, Q., Canagaratna, M. R., Allan, J., Coe, H., McFiggans, G., Rap, A., and Forster, P.: Aerosol mass spectrometer constraint on the global secondary organic aerosol budget, Atmos. Chem. Phys. Discuss., 11, 5699-5755, doi:10.5194/acpd-11-5699-2011, 2011.

Stuiver, M. and Polach, H. A.: Reporting of C14 Data - Discussion, Radiocarbon, 19, 355-363, 1977.

Sullivan, A. P., Peltier, R. E., Brock, C. A., de Gouw, J. A., Holloway, J. S., Warneke, C., Wollny, A. G., and Weber, R. J.: Airborne measurements of carbonaceous aerosol soluble in water over northeastern United States: Method development and an investigation into water-soluble organic carbon sources, J. Geophys. Res.-Atmos., 111, D23S46, doi:10.1029/2006jd007072, 2006.

Surratt, J. D., Murphy, S. M., Kroll, J. H., Ng, N. L., Hildebrandt, L., Sorooshian, A., Szmigielski, R., Vermeylen, R., Maenhaut, W., Claeys, M., Flagan, R. C., and Seinfeld, J. H.: Chemical composition of secondary organic aerosol formed from the photooxidation of isoprene, J. Phys. Chem. A, 110, 9665-9690, 2006.

Surratt, J. D., Kroll, J. H., Kleindienst, T. E., Edney, E. O., Claeys, M., Sorooshian, A., Ng, N. L., Offenberg, J. H., Lewandowski, M., Jaoui, M., Flagan, R. C., and Seinfeld, J. H.: Evidence for organosulfates in secondary organic aerosol, Environ. Sci. Technol., 41, 517-527, doi:10.1021/es062081q, 2007.

Surratt, J. D., Gomez-Gonzalez, Y., Chan, A. W. H., Vermeylen, R., Shahgholi, M., Kleindienst, T. E., Edney, E. O., Offenberg, J. H., Lewandowski, M., Jaoui, M., Maenhaut, W., Claeys, M., Flagan, R. C., and Seinfeld, J. H.: Organosulfate formation in biogenic secondary organic aerosol, J. Phys. Chem. A, 112, 8345-8378, doi:10.1021/jp802310p, 2008.

Surratt, J. D., Chan, A. W. H., Eddingsaas, N. C., Chan, M. N., Loza, C. L., Kwan, A. J., Hersey, S. P., Flagan, R. C., Wennberg, P. O., and Seinfeld, J. H.: Reactive intermediates revealed in secondary organic aerosol formation from isoprene, P. Natl. Acad. Sci. USA, 107, 6640-6645, doi:10.1073/pnas.0911114107, 2010.

Szidat, S., Jenk, T. M., Gäggeler, H. W., Synal, H. A. H. A., Fisseha, R., Baltensperger, U., Kalberer, M., Samburova, V., Reimann, S., Kasper-Giebl, A., and Hajdas, I.: Radiocarbon $\left({ }^{14} \mathrm{C}\right)$-deduced biogenic and anthropogenic contributions to organic carbon (OC) of urban aerosols from Zürich, Switzerland, Atmos. Environ., 38, 4035-4044, 2004.

Takahama, S., Davidson, C. I., and Pandis, S. N.: Semicontinuous measurements of organic carbon and acidity during the Pittsburgh air quality study: Implications for acid-catalyzed organic aerosol formation, Environ. Sci. Technol., 40, 2191-2199, doi:10.1021/es050856+, 2006.

Tobias, H. J., Docherty, K. S., Beving, D. E., and Ziemann, P. J.: Effect of relative humidity on the chemical composition of secondary organic aerosol formed from reactions of 1-tetradecene and $\mathrm{O}_{3}$, Environ. Sci. Technol., 34, 2116-2125, 2000.

Tolocka, M. P., Jang, M., Ginter, J. M., Cox, F. J., Kamens, R. M., and Johnston, M. V.: Formation of oligomers in sec- ondary organic aerosol, Environ. Sci. Technol., 38, 1428-1434, doi:10.1021/es035030r, 2004.

Tsimpidi, A. P., Karydis, V. A., Zavala, M., Lei, W., Molina, L., Ulbrich, I. M., Jimenez, J. L., and Pandis, S. N.: Evaluation of the volatility basis-set approach for the simulation of organic aerosol formation in the Mexico City metropolitan area, Atmos. Chem. Phys., 10, 525-546, doi:10.5194/acp-10-525-2010, 2010.

Tunved, P., Hansson, H. C., Kerminen, V. M., Strom, J., Dal Maso, M., Lihavainen, H., Viisanen, Y., Aalto, P. P., Komppula, M., and Kulmala, M.: High natural aerosol loading over boreal forests, Science, 312, 261-263, doi:10.1126/science.1123052, 2006.

Ulbrich, I. M., Canagaratna, M. R., Zhang, Q., Worsnop, D. R., and Jimenez, J. L.: Interpretation of organic components from Positive Matrix Factorization of aerosol mass spectrometric data, Atmos. Chem. Phys., 9, 2891-2918, doi:10.5194/acp-9-2891-2009, 2009.

Volkamer, R., Jimenez, J. L., San Martini, F., Dzepina, K., Zhang, Q., Salcedo, D., Molina, L. T., Worsnop, D. R., and Molina, M. J.: Secondary organic aerosol formation from anthropogenic air pollution: Rapid and higher than expected, Geophys. Res. Lett., 33, L17811, doi:10.1029/2006gl026899, 2006.

Volkamer, R., Martini, F. S., Molina, L. T., Salcedo, D., Jimenez, J. L., and Molina, M. J.: A missing sink for gas-phase glyoxal in Mexico City: Formation of secondary organic aerosol, Geophys. Res. Lett., 34, L19807, doi:10.1029/2007g1030752, 2007.

Wang, L., Atkinson, R., and Arey, J.: Dicarbonyl products of the $\mathrm{OH}$ radical-initiated reactions of naphthalene and the $\mathrm{C}-1-$ and C-2-alkylnaphthalenes, Environ. Sci. Technol., 41, 2803-2810, doi:10.1021/es0628102, 2007.

Warneke, C., de Gouw, J. A., Stohl, A., Cooper, O. R., Goldan, P. D., Kuster, W. C., Holloway, J. S., Williams, E. J., Lerner, B. M., McKeen, S. A., Trainer, M., Fehsenfeld, F. C., Atlas, E. L., Donnelly, S. G., Stroud, V., Lueb, A., and Kato, S.: Biomass burning and anthropogenic sources of CO over New England in the summer 2004, J. Geophys. Res.-Atmos., 111, D23s15 doi:10.1029/2005jd006878, 2006.

Weber, R. J., Sullivan, A. P., Peltier, R. E., Russell, A., Yan, B., Zheng, M., de Gouw, J., Warneke, C., Brock, C., Holloway, J. S., Atlas, E. L., and Edgerton, E.: A study of secondary organic aerosol formation in the anthropogenic-influenced southeastern United States, J. Geophys. Res.-Atmos., 112, D13302, doi:10.1029/2007jd008408, 2007.

Williams, B. J., Goldstein, A. H., Kreisberg, N. M., and Hering, S. V.: An in-situ instrument for speciated organic composition of atmospheric aerosols: Thermal Desorption Aerosol GC/MS-FID (TAG), Aerosol Sci. Technol., 40, 627-638, 2006.

Williams, B. J., Goldstein, A. H., Millet, D. B., Holzinger, R., Kreisberg, N. M., Hering, S. V., White, A. B., Worsnop, D. R., Allan, J. D., and Jimenez, J. L.: Chemical speciation of organic aerosol during the International Consortium for Atmospheric Research on Transport and Transformation 2004: Results from in situ measurements, J. Geophys. Res.-Atmos., 112, D10S26, doi:10.1029/2006JD007601, 2007.

Williams, B. J., Goldstein, A. H., Kreisberg, N. M., and Hering, S. V.: In situ measurements of gas/particle-phase transitions for atmospheric semivolatile organic compounds, P. Natl. Acad. Sci. USA, 107, 6676-6681, doi:10.1073/pnas.0911858107, 2010a.

Williams, B. J., Goldstein, A. H., Kreisberg, N. M., Hering, S. V., Worsnop, D. R., Ulbrich, I. M., Docherty, K. S., and Jimenez, J. 
L.: Major components of atmospheric organic aerosol in southern California as determined by hourly measurements of source marker compounds, Atmos. Chem. Phys., 10, 11577-11603, doi:10.5194/acp-10-11577-2010, 2010b.

Worton, D. R., Goldstein, A. H., Surratt, J. D., Seinfeld, J. H., Glasius, M., Kristensen, K., Farmer, D. K., Docherty, K. S., Jimenez, J. L., Bouvier-Brown, N. C., Gilman, J. B., Kuster, W. C., and de Gouw, J.: Measurements of organosulfates, nitroxyorganosulfates and acids observed during the biosphere effects on aerosol and photochemistry experiment, to be submitted to Atmos. Chem. Phys., 2011.

Yu, J. Z., Flagan, R. C., and Seinfeld, J. H.: Identification of products containing $-\mathrm{COOH},-\mathrm{OH}$, and $-\mathrm{C}=\mathrm{O}$ in atmospheric oxidation of hydrocarbons, Environ. Sci. Technol., 32, 2357-2370, 1998.

Yu, J. Z., Cocker, D. R., Griffin, R. J., Flagan, R. C., and Seinfeld, J. H.: Gas-phase ozone oxidation of monoterpenes: Gaseous and particulate products, J. Atmos. Chem., 34, 207-258, 1999a.

Yu, J. Z., Griffin, R. J., Cocker, D. R., Flagan, R. C., Seinfeld, J. H., and Blanchard, P.: Observation of gaseous and particulate products of monoterpene oxidation in forest atmospheres, Geophys. Res. Lett., 26, 1145-1148, 1999b.
Zhang, Q., Worsnop, D. R., Canagaratna, M. R., and Jimenez, J. L.: Hydrocarbon-like and oxygenated organic aerosols in Pittsburgh: insights into sources and processes of organic aerosols, Atmos. Chem. Phys., 5, 3289-3311, doi:10.5194/acp-5-32892005, 2005.

Zhang, Q., Jimenez, J. L., Canagaratna, M. R., Allan, J. D., Coe, H., Ulbrich, I., Alfarra, M. R., Takami, A., Middlebrook, A. M., Sun, Y. L., Dzepina, K., Dunlea, E., Docherty, K., DeCarlo, P. F., Salcedo, D., Onasch, T., Jayne, J. T., Miyoshi, T., Shimono, A., Hatakeyama, S., Takegawa, N., Kondo, Y., Schneider, J., Drewnick, F., Borrmann, S., Weimer, S., Demerjian, K., Williams, P., Bower, K., Bahreini, R., Cottrell, L., Griffin, R. J., Rautiainen, J., Sun, J. Y., Zhang, Y. M., and Worsnop, D. R.: Ubiquity and dominance of oxygenated species in organic aerosols in anthropogenically-influenced Northern Hemisphere midlatitudes, Geophys. Res. Lett., 34, L13801, doi:10.1029/2007g1029979, 2007a.

Zhang, Q., Jimenez, J. L., Worsnop, D. R., and Canagaratna, M.: A case study of urban particle acidity and its influence on secondary organic aerosol, Environ. Sci. Technol., 41, 3213-3219, doi:10.1021/es061812j, 2007b. 